$50 \mid 2019$

Animals in the religion and culture of the Tibetan

Plateau

\title{
When the tiger meets Yul 'khor srung, or how to protect a construction site
}

Quand le tigre rencontre Yul 'khor srung, ou comment protéger un site de construction

\section{Petra Maurer}

\section{(2) OpenEdition Journals}

Electronic version

URL: https://journals.openedition.org/emscat/3950

DOI: 10.4000/emscat.3950

ISSN: 2101-0013

\section{Publisher}

Centre d'Etudes Mongoles \& Sibériennes / École Pratique des Hautes Études

\section{Electronic reference}

Petra Maurer, "When the tiger meets Yul 'khor srung, or how to protect a construction site", Études mongoles et sibériennes, centrasiatiques et tibétaines [Online], 50 | 2019, Online since 04 March 2019 connection on 13 July 2021. URL: http://journals.openedition.org/emscat/3950 ; DOI: https://doi.org/ 10.4000/emscat.3950

This text was automatically generated on 13 July 2021 .

(c) Tous droits réservés 


\title{
When the tiger meets Yul 'khor srung, or how to protect a construction site
}

\author{
Quand le tigre rencontre Yul 'khor srung, ou comment protéger un site de \\ construction
}

Petra Maurer

1 For an animal that is not widespread on the Tibetan Plateau, and has never lived in large numbers at high altitudes ${ }^{1}$, tigers make a surprisingly large and diverse number of appearances in Tibetan divination and especially geomancy. This article looks at the various roles these animals play and tries to explain how they ended up in Tibetan divinatory texts ${ }^{2}$.

2 The article begins with a brief introduction to Tibetan geomancy (sa dpyad) and the culturally complex and ambivalent terminology used to describe it. It will explain the relationship between Chinese geomancy or fengshui 風水 and Tibetan geomancy, describing the elements of the Chinese tradition that are essential to understanding the Tibetan concept of sa dpyad. Some of these findings are not new, but will be presented in a new light and for the sake of completeness.

3 The second part of the article will deal with the various contexts in which the tiger is introduced in the Tibetan tradition and look at the Tibetan adaptation of the Chinese geomantic theories associated with it. These theories include the spatiotemporal model of contrasting or complementary forces related to four animals that are the dragon, bird, tiger and turtle. The topographical forces specifically significant in geomancy are called "dragon and tiger".

4 The main part of the study refers to chapter 32 of the White Beryl (Vaidürya dkar po) written by Sangs rgyas rgya mtsho (1653-1705), the Fifth Dalai Lama's regent. The article also refers to other traditions such as the writings of Kong sprul blo gros mtha' yas (1813-1899). This extraordinarily learned Tibetan scholar transmitted a tradition of Tibetan geomancy, which focused on "dragon and tiger" to distinguish topographical 
characteristics. After these explanations, the article will describe the tiger's astrological and divinatory functions more broadly and the symbolism of the tiger more generally. It will show the tiger's descriptive or metaphorical use in topographical explanations, and its application and function in rituals related to Tibetan geomancy.

Figure 1. Tiger and dragon

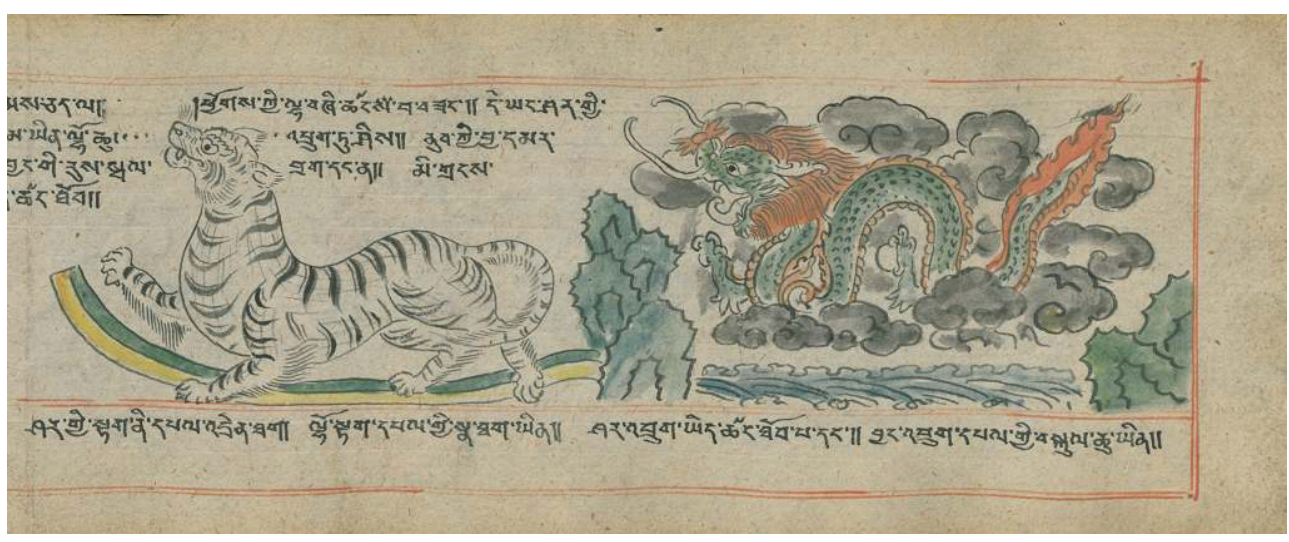

Bavarian State Library, Cod.tibet.896.

(C) Bavarian State Library

\section{Terminological reflections on sa dpyad and geomancy}

\section{Reflections on sa dpyad}

Divinatory techniques in general and of $s a$ dpyad in particular strongly influenced Tibetan culture and shaped Tibetan life. Sa dpyad, which means more literally "the examination of the land", is a technique within the Tibetan field of knowledge called nag rtsis, "Chinese calculation" including mathematics, astrology, astronomy and divination ${ }^{3}$. When we discuss the complex of systems related to sa dpyad, we usually use the English term "divination" to describe it. This is quite problematic. Divination is literally derived from Latin divinare: "to predict the will of the gods". In its broader interpretation, it is understood to mean "to explore, reveal and predict the unknown", usually with a focus on the future. In the context of these Tibetan and Chinese traditions, both the terms divination and the more specific geomancy, which is often used to translate sa dpyad are unsuitable and unsatisfactory for several reasons.

To explain the system briefly, the geomantic method includes two procedures that are related to an area's topography. As it is described in Tibetan sources, the first of these is the examination of the land, its identification and the interpretation of its topographical characteristics in order to find a suitable site for construction. Then, in the second phase of this first process, the site in question is assessed as suitable or unsuitable. These procedures are called dpyad, a term that means also "analysis" and in medical texts "diagnosis". The other procedure is also connected to the topographical features, but it involves the diviner or astrologer (rtsis mkhan) calculating several dimensions to determine a suitable place for construction. Depending on the elements of the client's birth year, the diviner assesses topographical shapes as suitable or unsuitable for the construction of someone's home ${ }^{4}$. 
7 Already this explanation shows how slippery and sometimes inappropriate the indigenous designations for these practices are, let alone their translations in European languages. The Tibetan designation only refers to the first of these two methods: there are no syllables that mean "calculation" in the Tibetan term used to define this practice. One could argue that a site's topography is involved in both procedures and therefore "examination and analysis of the land" says enough. However, the terminology still ignores the important factor of time and timing that can influence the search for the right place to construct a building. The birth year, for example, determines if one should settle in a certain place; it shows the link between past and present. As a result, the diviner can apply geomantic divination as a technique to explain the presence and the future by assessing or calculating one's birth, i.e. the past.

Whatever technique is applied, be it the interpretation of shapes or calculation, the written sources repeatedly explain the consequences of erecting a building in certain places. That is to say, the prognosis for the inhabitants when they construct their house in such and such a place is fixed. Although the explicitly conditional clause might be missing in the phrases, the protasis and apodosis are implicit ${ }^{5}$; I will come back to this later. The main process and the task of the diviner or prognosticist is therefore to interpret the shapes, to recognize and to identify them. Understanding these phenomena was of major importance; the prognosticist usually studied the complete spectrum of nag rtsis for example in the Medical-Astrological Institute (sman rtsis khang) in Lhasa. He was not only trained in calculations, but also in the interpretation of topographical shapes: while studying sa dpyad he formed the shapes of the land with sand in order to correctly identify the topography.

9 This shows that "geomantic prognostication" or "geomantic divination" obviously merges various methods inseparably. We cannot take these prediction methods apart they are based on calculation and interpretation of topography - in the same way as the various sciences were separated from one another in $18^{\text {th }}$ and $19^{\text {th }}$ century Europe ${ }^{7}$.

\section{The practice of "geomancy"}

10 Like the use of the word divination, the use of the English term geomancy to translate sadpyad is also problematic. This word, "geomancy", can be interpreted in two different ways: like sa dpyad it can refer to the "characteristics of the land", that is, the interpretation of topographical features of an area, and this corresponds to one of the methods applied in Chinese fengshui 風水 (“wind water") ${ }^{8}$. The problem with using the term "geomancy" is that it also denotes the analysis of patterns or forms drawn or produced in sand or any other kind of soil. This divinatory technique was practised in the Arabic-Islamic world, medieval Europe, parts of Africa and northern India. A diviner, someone who predicts the future, produces in the soil or sand random patterns that are an arrangement of dots or lines, or else dots and lines that are drawn following special rules. He analyses these patterns to predict someone's future. This procedure is not specifically connected with the construction of a building. The other, even more precise term to render this form of "geomancy" is the German term Punktierkunst, the "art of dotting", also called "psammomanty". This form of divination eventually turned into pebble divination in Tibet".

When I was looking for possible influences on Tibetan sa dpyad, I came across the Sanskrit term ramala, derived from Arabic term raml, ilm al raml or more precisely al- 
khatt bi $\mathrm{ram}^{10}$. It spread in India with the Mughal emperors, but as written sources are rare it seems not to have been very widespread. Monier-Williams, however, interprets ramala as "a mode of fortune-telling by means of dice (s. branch of divination borrowed from the Arabs)". To what extent the technique was applied in India is not known, but the number of manuscripts on ramala is much smaller than texts on Vāstuvidya architecture. The oldest datable manuscript, the Ramalavaicitrya or Ramalabhāskara, was written in the $17^{\text {th }}$ century ${ }^{11}$. Monier-Williams might refer to a different performance of this divinatory technique, that is the use of pebbles to perform geomantic practices. In Tibetan culture for example, pebble divination creates patterns identical with psammomantic signs from $16^{\text {th }}$ century Europe. This method of divination depends more or less on coincidence ${ }^{12}$. A representative of the tradition applied in medieval Europe is Agrippa von Nettesheim (1486-1535), who explains it in the second volume of his De occulta philosophia $\left(1533^{13}\right)$.

Geomancy and the art of dotting use patterns or forms to predict the future and/or analyse current situations. However, these techniques show two major differences: while geomancy focuses on the construction of buildings, and its predictions concern any aspect of life, the art of dotting is a technique applied to request an answer for the future more generally. And while the art of dotting produces forms and patterns, the forms and patterns used in geomancy exist naturally in the environment and are not produced artificially. There is some crossover in how the two words are used, but they are not even rough equivalents.

These reflections lead back to the Tibetan term sa dpyad, and the same conundrum. If we use the term "geomancy", with some hesitation, and combine it with the appropriate term prognostication, we are still left with the same problem as the Tibetan original: all these terms ignore the calculations inherent in the tradition.

These terminological reflections show that many of the items or phenomena interpreted for prognostication are ubiquitous in the lands where they are used. With regard to Tibet, we may, therefore, assume that some if not many of the divinatory practices originate elsewhere. They may come from the pre-Buddhist inhabitants of the Tibetan Plateau, from China, India or any other Central Asian country, if not from countries even further away such as from the Islamic world ${ }^{14}$.

\section{The myth on the adoption of sa dpyad}

According to historiographical sources, sa dpyad was - like most traditional sciences, the Tibetan script and Buddhism - introduced into Tibet with the beginning of the great empire under king Srong btsan sgam po in the $7^{\text {th }}$ century. The Chinese princess Wencheng 文成, also called Kong jo (from Chinese gongzhu 公主) by the Tibetans, probably the niece of the emperor Taizong太宗 of the Tang dynasty, became Srong btsan sgam po's wife. Tibetan tradition states that it was she who established the practice and knowledge of geomantic prognostication in Tibet when she interpreted the land in the area that later became the capital of Tibet, Lhasa ${ }^{15}$. Other sources, however, the $14^{\text {th }}$ century Clear Mirror of Royal Genealogies (rGyal rabs gsal ba'i me long) and the $20^{\text {th }}$ century The Wish-Fullfilling Tree (dPag bsam ljong shing) date the beginnings of the transmissions in the time of this technique to the reign of Srong btsan sgam po's father, gNam ri srong btsan. The Clear Mirror says: "During the time of this king, [the art of] medicine and divination were introduced from China ${ }^{16 " . ~}$ 

For although geomantic prognostication was a non-Buddhist tradition, tradition has it that it was used to tame the Plateau's indigenous spirits, particularly the demoness that represented the land from a geomantic perspective, and thus to allow the introduction of Buddhism. lakes on the Plateau; the lake gNam mtsho phyug mo, for example, which is sacred to Buddhists and Bonpos, is regarded as a demoness lying on her back ${ }^{17}$. The isomorphy that is the identification of the land with the demoness is similar to the procedure applied frequently in Tibetan geomancy when certain topographic characteristics are compared with humans, animals, deities and demons. The idea of identifying the land with the body of a demoness could go back to a non-Buddhist myth told in The Hundred Thousand Water Spirits (Klu 'bum). According to the myth articulated in this text, the world originates from a female serpent spirit, a klu mo: the sky, for example, originates from the head, the sun and moon from the eyes, the four planets from four upper teeth. The twelve upper and the twelve lower teeth turn into the lunar mansions. The veins turn into the rivers, a concept that reminds one of the Chinese dragon with its veins as rivers ${ }^{18}$. Sangs rgyas rgya mtsho (1653-1705) describes a similar myth in his White Beryl (Vaidürya dkar po): the world originates from a golden turtle; the sky orignates from the turtle's mind, the water is identified as its blood, the eight planets as its teeth, while the lunar mansions are its dorsal vertebrae ${ }^{19}$.

18 These tales show that the identification of land with a goddess or demon or with an animal is a common feature in several myths, and there are others that would be worth studying. The technique of comparing an area with a body or body parts is widely applied in Tibetan geomancy to assess the land.

\section{The tiger in Tibet and geomantic prognostication}

19 Along with many other animals, the tiger and its body parts are frequently used to describe the shapes of places. Despite their scarcity at high altitude, they are more commonly used to describe landscapes than, for example, the ubiquitous yak.

The tiger (Panthera tigris) is easy to identify by its stripes and his reddish-orange coloured fur. It is the largest cat species; other species of this genus are the lion, leopard, jaguar and the snow leopard. The tiger was endemic to southeastern Tibet and lived across eastern Eurasia. It is not surprising therefore, that it was chosen as a symbol in fengshui, and through fengshui was introduced to Tibet ${ }^{20}$.

Its highly symbolic meaning in Tibet and in its main neighbouring cultures, China and India, influenced its imagery. In China, the tiger represents mammals, and is endowed with qualities similar to those of the lion in India: fearlessness, strength and military prowess. In Chinese and Tibetan medicine, the tiger's bones, whiskers, claws, and the ash produced from its fur are also applied to cure various ailments ${ }^{21}$. On Tibetan thangkas, hermits, yogins and deities are depicted with a tiger skin that serves them as a pad upon which they can sit; sometimes the tiger skin is wrapped around their waist. The great Tibetan yogin, Milarepa (1040-1123), for example, is often depicted on a tiger skin. Using tiger skin as a seat goes back to an Indian myth. In this myth, siva killed the 
tiger, which symbolised desire. Therefore, to sit on the skin demonstrates that the seated figure has overcome desire. The tiger is, moreover, the mount of wrathful deities like Vārāhī (originally an Indian mother goddess but adopted in Tibet), Durgā or Kālī. The Bodhisattva Mañjuśrī occasionally rides a tiger, too.

The animal represents powerful and wrathful activities; it symbolises protection against harmful influences and protects the one sitting on its skin against snakes and scorpions. The tiger stripes are a famous motif in Tibetan carpets and furniture. A pair of cylindrical decorations at each side of the door ('bog lcag or stag sgril) adorned the entrance to the Dalai Lama's room and the rooms of other important lamas. The skin also adorns the Tibetan victory banner ${ }^{22}$.

\section{The tiger and the dragon in fengshui}

In the Chinese tradition of fengshui, the tiger and dragon occur together as the two most highly symbolic animals. Fengshui was and still is of a major importance in China, and was often closely related to ancestor worship and the construction of graves. The respective land had to be examined very carefully before these graves were constructed. Generally, the principles of fengshui were supposed to ensure that wellbeing and prosperity of descendants could be ensured; a grave in suitable surroundings was said to ensure this ${ }^{23}$.

The earliest examples of the tiger and dragon are said to be found in Neolithic graves in Henan province; these graves were excavated by the late 1980s and dated by some to the Yangshao culture (5000 to $3000 \mathrm{BC}$ ). In these graves, a dragon and a tiger made of shells are placed beside the skeleton of a male ${ }^{24}$. Those who doubt the early dating for this cave nevertheless suggest that the use of the tiger and dragon is evidenced during the ancient Han dynasty in the $3^{\text {rd }}$ century AD.

The oldest known written sources to discuss the tiger and dragon are the bamboo slips from the Han dynasty housed at Beijing University. Strip number 27 is dedicated to military strategy - according to the principles of yin and yang - and victory in battle. The most striking thing about this slip is the addition of a third animal. In this work, mountains are designated as dragons, hills as leopards, and mounds as tigers. Even at this early stage, there are familiar patterns from fengshui; mountains, it suggests, should be on the left side of a building and rivers to the right ${ }^{25}$.

In this work and later, the two animals are thought to correspond to the concept of yin 陰 and yang 陽, two ambivalent or complementary dimensions that identify and determine the energy of an area ${ }^{26}$. The female principle is yin; it denotes the shady side, the northern slope of a mountain, the lower hills and the southern side of a river. Round elevations are assessed as yin and therefore identified as the white or whitish tiger who is at the same time related to the right side, the west. The male principle yang symbolises the sunny side, the southern slope which is high and steep, and the northern side of a river. These topographic characteristics symbolise the blue, azure, green or turquoise dragon. The dragon is also associated with the left side, the east. Thus, dragon and tiger determine the topography of a place ${ }^{27}$. The land is assessed as suitable if its energy is balanced. In other words, the dragon, the eastern hill, should be higher than the tiger, while the western hill, and the best building ground is where the loins of the tiger and dragon meet. 
Besides the shapes of the land, its mountains and the flow of the rivers and the position of lakes and so on, a major element of geomantic analysis is to understand the distribution of $q i$ 氣 28 .

$Q i$ is the energy in the land that permeates flora and fauna, and all animate and inanimate beings. If the prognosticator includes nature and the environment in his or her plans, and orientates the construction according to natural conditions, s/he can influence his or her own destiny in a positive or in a negative way. Therefore, $s / h e$ should construct buildings - be it a grave or a house for the living - in places where s/ he can use and take advantage of the circulating qi. This will influence his/her future in a positive way. He or she should, therefore, build in a place that enables him or her to maximise positive and minimise negative effects. Qi or vital energy is also referred to as the dragon's or tiger's breath, and is a precondition for understanding Chinese fengshui. Prevailing ideas include the dispersion of $q i$ by wind ( $f e n g$ 風) and its absorption by water (shui 水). Wind and water influence the land antagonistically but in a harmonising way. The negative type of $q i$ is sha 殺 which might be translated as “noxious pneuma"; there is also sha qi 殺氣 or feng sha 風殺 “harming wind”. Both positive and negative qi are shaped by the contours of a land ${ }^{29}$.

Any straight lines in an area - be they natural like mountain ranges or river or artificially created like railways or electric cables - reduce the effect of qi. The negative effects of sha can be obstructed by a wall; this is why the entrances to temples or the Forbidden City are protected by walls $\mathrm{s}^{30}$. Simple profane buildings can be protected by artificial ponds, vessels with water or trees. Flowing waters weaken fengshui; they carry away positive energy. Pagodas can minimize this effect. If the fengshui is really bad, major procedures may be needed, like the diversion of a river or the removing or piling up of an entire hill ${ }^{31}$. In this way, fengshui was understood to be a method to change an unpleasant power, an unsuitable or even destructive energy of an area and to transform it into a positive energy.

The earliest accounts of yin and yang are found in the Zhouyi, the oldest edition of the Yijing 易经 or The Book of Changes. The Yijing contains a collection of the trigrams used for prediction, explained in its commentary, the Xicizhuan. These trigrams are a combination of broken (yin) and unbroken lines (yang), they are understood to be reflections or symbols of events ${ }^{32}$. They are related to the four directions and the four intermediate directions and are arranged in two different ways. One of the ways of arranging the trigrams is said to have originated with Fuxi, the triagrams' inventor. The other is said to have been organized by King Wen 文王, the founder of the Zhou Dynasty (11-256 BC). The order King Wen developed is called the Luo-Shu-square 洛書, which forms the basis for the order of the spar kha and sme ba in Tibetan astrology ${ }^{33}$. The following chart, based on the order King Wen developed, shows the clockwise order of the trigrams starting in the south, as the compass is oriented towards south and not towards north. 
Table 1. Trigrams in the "Later Heaven Sequence"

\begin{tabular}{|l|l|l|l|l|}
\hline $\begin{array}{l}\text { Trigram } \\
\text { Chinese / Tibetan }\end{array}$ & $\begin{array}{l}\text { Gender aspect } \\
\text { Chinese / Tibetan }\end{array}$ & $\begin{array}{l}\text { Direction } \\
\text { "Later Heaven } \\
\text { Sequence" }\end{array}$ & $\begin{array}{l}\text { Element and } \\
\text { Animal }\end{array}$ & Number \\
\hline li 離 / li & yin / mo & South & fire, boar & 9 \\
\hline kun 坤 / khon & yin / mo & Southwest & earth, hare & 2 \\
\hline dui 兑 / dva & yin / pho & West & $\begin{array}{l}\text { water, snake's } \\
\text { head }\end{array}$ & 7 \\
\hline qian 乾 / khen & yang / pho & Northwest & metal, horse & 6 \\
\hline kan 坎 / kham & yang / pho & North & water, dragon & 1 \\
\hline gen 艮 / gin & yang / pho & Northeast & wood, tiger & 8 \\
\hline zhen 震 / zin & yang / mo & East & $\begin{array}{l}\text { wood, guardian } \\
\text { monkey }\end{array}$ & 3 \\
\hline xun 巽 / zon & yin / mo & Southeast & wood, hen & 4 \\
\hline
\end{tabular}

31 This is the order applied in Tibetan prognostication, but the relation of the elements or agents does not completely coincide. Tibetans assign the wood element only to the east and the element earth to the intermediate directions ${ }^{34}$.

The elements or agents ${ }^{35}$ arise from the various relations and changes of yin and yang; they not only characterise the substances but also create a cycle of mutual production and destruction: these are wood, fire, earth, metal ${ }^{36}$ and water. Fire generates earth; earth generates metal; metal generates water; water generates wood; and wood creates fire. Wood overcomes earth, earth overcomes water, water overcomes fire, fire overcomes metal and metal overcomes wood. Spring and summer are considered yang, autumn and winter yin; the dimensions change during the solstice. During the summer solstice, yang comes to dominate and during the winter solstice, yin has the strongest power.

The relation of all these powers and dimensions influenced Tibetan sa dpyad. The Tibetans imported many of these ideas, including the Later Heaven Sequence with its designation of the trigrams to the directions shown in the chart above. Tibetan prognosticators calculated the elements, and the trigrams, which they called spar kha as well.

\section{The four animals}

The main directions of the dragon and tiger are, respectively, east and west. But as we have seen, the dragon and tiger are also assigned to the sunny northern and shady southern sides of hills. In the Chinese cosmic concept, there are usually two other animals that take the northern and southern positions: a red bird, a phoenix or sometimes a sparrow ${ }^{37}$, is assigned to the south and a turtle or a turtle wrapped in a snake is called "the black warrior" and is assigned to the north. The earliest source that mentions these four animals is the Book of Burial 葬書 ${ }^{38}$. In this tradition, the animals are assigned to the four quarters of the heavens, four colours (dark blue, white, vermilion and black), four elements or agents and the four seasons: the dragon is spring, the bird is summer, the tiger is autumn and the turtle is winter. They also act as symbols for larger groups of animal species: the tiger represents all hairy mammals, the dragon represents the scaly creatures like fish or reptiles, the turtle shell represents covered invertebrates and the bird represents feathered animals. The tiger 
is the tiger and is consistently depicted as such. The other three animals keep on changing their shape, especially the dragon and the bird. Since Han times, the turtle has appeared as the "black warrior ${ }^{39}$ ".

A building, be it a grave or a house, has a positive effect if the four animals are placed in four specific directions. All dwellings that have the following features are considered very honorable: flowing water, which is the azure dragon on their left, a long path representing the white tiger on their right, a pool in front that represents the red bird, and hillocks behind, which indicate the turtle or the black warrior ${ }^{40}$. The so-called "School of Forms", a division of fengshui practice, furthermore, particularly emphasised a site's topography; here, the distinction of a place's shape is a decisive factor for the construction of buildings ${ }^{41}$. All four animals symbolise topographical features that are regarded as positive or negative for the construction of a building. Through all these relations, they are assigned to yin and yang too. These patterns are difficult to interpret and understand; only a person trained in its interpretation, that is, the prognosticator, is able to read the land.

The sites identified as the tiger can be assessed positively or negatively. They can cause poverty and childlessness or wealth ${ }^{42}$. An auspicious place is one in which the four animals are in their right directions: "It is auspicious to bury the dead in a place with the dark-blue dragon on the left, the white tiger on the right, the vermilion bird in the front, and the dark tortoise at the back ${ }^{43}$ ".

The associations with these four animals spread from China into Central Asia and Tibetan cultural areas to ${ }^{44}$. Moreover, as will be shown later, they are found in various traditions such as in Bon mythology, the Gesar epic and Ladakhi folk songs. All traditions place one animal in one direction ${ }^{45}$.

\section{The tiger and the dragon in Tibetan sa dpyad}

The image of the tiger and the dragon as a duo was adapted by the Tibetans in much the same way, and it is pervasive in Tibetan sa dpyad. Within the Tibetan tradition, this pairing is presented in different ways. The form in which it has the closest affiliation to the Chinese, fengshui presentation amongst the works I investigated was in a work by the $19^{\text {th }}$ century, non-sectarian (ris med) polymath from eastern Tibet, Kong sprul blo gros mtha' yas (1813-1899). Volume Ta of his Extensive Treasury of Pronouncements (rGya chen bka' mdzod) includes thirteen chapters he composed on sa dpyad under the heading A Magical Key That Opens the Gate to Chinese Geomancy, According to the Tradition of the New Translation (Tsi na'i sa dpyad gsar 'gyur lugs kyi sgo 'byed 'phrul gyi lde'u mig ces bya ba ${ }^{46}$ ). In this work, he assigns the tiger to the right or west side, and the dragon to the left or east side. "The mountain on the right side is the tiger and the mountain on the left side is the dragon" (g.yas ri stag dang g.yon ri 'brug). This assignment corresponds to the Chinese tradition.

Kong sprul dedicates chapter three explicitly to the dragon, and chapters seven and eight relate to the tiger-dragon-concept. He calls it, "the examination of the union of dragon and tiger and so on" (stag 'brug g.yab sogs dpyad). The Tibetan term g.yab in this title literally means "shelter, covered place", and renders the Chinese concept of the place where the loins of tiger and dragon meet, which is to say the place with the best conditions for construction. The explanations Kong sprul presents in this work differ from the rest of the Tibetan tradition. He assigns the elements to mountain shapes and 
emphasizes tiger and dragon symbolism in a way I have not encountered in other Tibetan sources. More commonly, Tibetan prognosticators identify the turquoise dragon (g.yu 'brug) on the left side and the light or white tiger (stag dkar) on the right side as mountains at the right and the left side of village. They do not talk about the place where the loins of the two animals meet.

\section{The four animals in Tibetan sources}

The more usual way to find the tiger and dragon depicted in the sa dpyad tradition is along with the other two animals that round out the fengshui foursome. In the Tibetan context, however, the assignment of these four animals - who are also called the four protectors (srung bzhi) - differs from the original Chinese tradition. There are also several variants of the tradition within Tibet.

Figure 2. Four animals as mountains

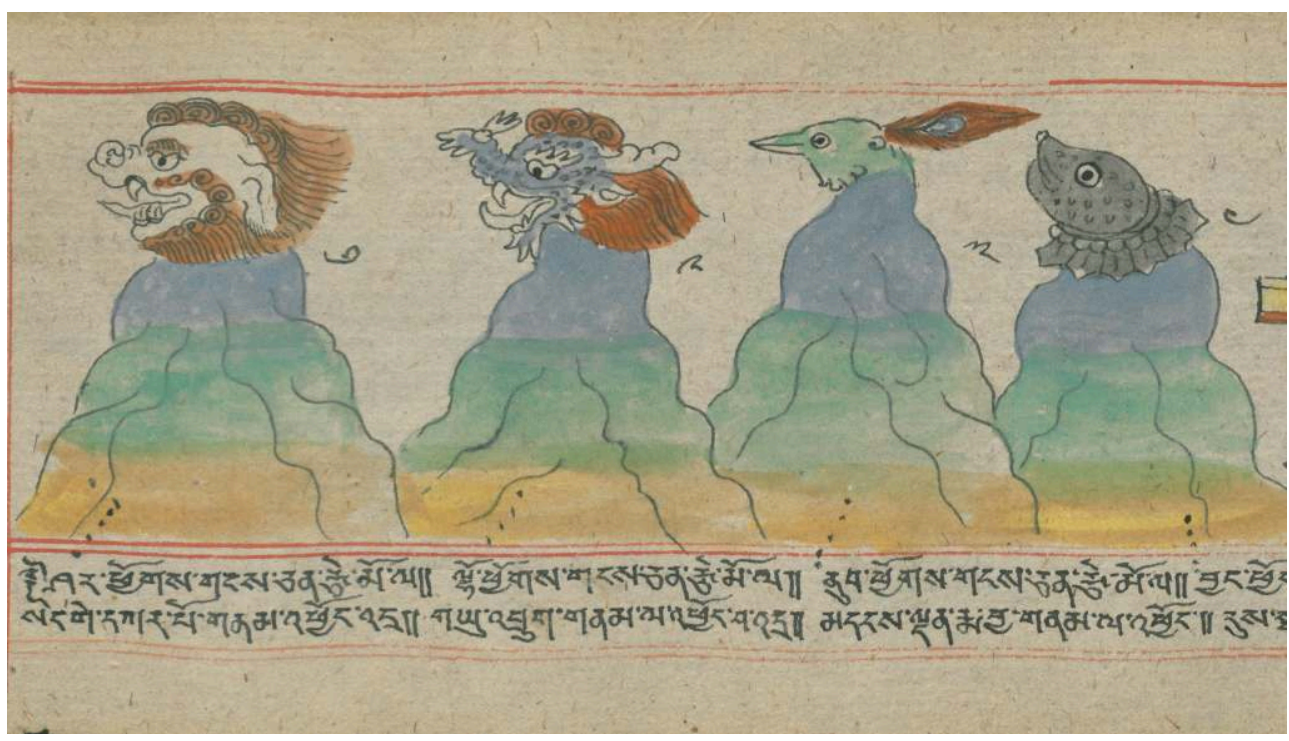

Bavarian State Library, Cod.tibet.897.

(C) Bavarian State Library

41 According to the myth of these four animals that the Clear Mirror of Royal Genealogies expounds, the Chinese princess Wencheng interpreted topographic features related to these four animals in the four cardinal directions. Her point of view is from the heart of the demoness, that is to say the lake called "milk plain" ('O thang) that used to exist on the site of present day Lhasa. Having seen these animals in the landscape, she recommended that four "border taming [temples]" ( $m$ tha' 'dul) be erected in these areas to tame the demoness that was identified with the land itself. In the east, she recognized the mountain symbolising the whitish tiger; in the south, she recognised the Lhasa River as a green dragon; in the west and north she recognised mountains symbolising, respectively, the red bird or phoenix and the black turtle. Nel pa Pandita's ${ }^{47} 13^{\text {th }}$ century Tibetan chronicle the Garland of Flowers (Me tog phreng ba), however, assigns some of these animals to other directions. It suggests that the four temples were constructed on the blue dragon's feather in the east, on the whitish 
tiger's canine tooth in the south, on the red bird's beak in the west and on the black turtle's forehead in the north.

In whatever direction the animals might be placed, the story still combines two independent traditions. The first of these is the myth, possibly of Bon origin, that identifies the land with the demoness. She is pinned down at certain body parts to facilitate the establishment of Buddhism in Tibet by overcoming the spirits or demons that the demoness enables to move in the Tibetan Plateau. Buddha is said to be already present at this point, but concealed. He only becomes visible when the temples are erected in favourable sites that are identified as the demonesses body parts. This imagery represents the fact that, when Wencheng came to Tibet, Buddhism was already introduced though not firmly established. The other element of the story is that the spatiotemporal animal deities of the Chinese cosmic concepts are then superimposed onto this identification of Tibet with both demoness and the contemporaneous but latent Buddha ${ }^{48}$. It is therefore not surprising that the dragon is associated with water and not with a mountain, for in fengshui, the dragon is related to water.

\section{The four animals in the White Beryl}

The most influential of the texts that discuss the four animals, however, are not the historiographical works that talk about their first recognition in Tibet, but the discussion of them in the White Beryl by sde srid Sangs rgyas rgya mtsho. Within this enormous compendium on the complete sciences called nag rtsis, chapter 32 examines sa dpyad.

Throughout this text, Sangs rgyas rgya mtsho refers to the four animals in various contexts. His first reference to them is quite striking. It occurs in a passage on "the outer characteristics" that describes unsuitable construction sites. There, Sangs rgyas rgya mtsho calls the animals the "four bad deities" (lha bzhi ngan ${ }^{49}$ ). These are described along with four "unsuitable colours of the ground or rocks", "bad water" and "bad trees" and so on.

His description in the first section aligns with the way the animals are conceptualised in fengshui. The four animals are assigned to their appropriate directions and to topographic aspects that are particularities of the environment, such as a path, a river, a grove, a rock and a meadow. He assesses the site as positive. Possible failures of the topography that he declares as adversarial are:

A path is the whitish tiger. Water is the dragon. A grove is the bird. A rock and a meadow $^{50}$ are the turtle. The tiger in the west is the corpse's path. The tiger in the north is the enemy's horse. The bird of the north is ominous. He is called "enemy attack" and is bad. Even if the four deities in the four directions are complete, [a path] in a flood area or on a spur will still be the tiger's adversary. If a bridge is constructed over the river, it will be the dragon's adversary. If [the grove] is cut off by an enclosure or path, this will be adversarial to the bird. The turtle's adversaries are caves [in the rock] and dben $r t s a^{51}$. If the deities are positioned in one of these adversarial positions, it is bad ${ }^{52}$.

In the following passage, he describes an increase in the site's unsuitableness for construction:

If bad water flows quickly in the middle of the path it becomes a "tiger's corpse". If a meadow emerges in the middle of a river, it is a "dragon's corpse". A meadow and a rock in the middle of a grove ${ }^{53}$ are "the bird's corpse". At the edge of a meadow, 
the entrance of the path is cut off. If the marsh area is endless, the entrance of the path is cut off. If there is a tree trunk with a cut down canopy, a decomposed tree [or a tree] with a bald canopy it is "the northern turtle's corpse". These corpses are very bad ${ }^{54}$. If a big mountain is visible in the east, a vast sky in the north (this means open space), and a great plain in the west, then this is bad $\mathrm{d}^{55}$. indicate that these sites are unsuitable for construction because the topographic characteristics assigned to the animals are disturbed, either by naturally occurring events or by construction projects. A flooded path or a bridge over the river obstructs the flow of energy. If a high mountain in the back is identified as a turtle, a cave, a "hole", weakens its protective power. The topographic rules in fengshui are quite explicit: "A dark turtle whose head is not lowered in respect appears to repel the corpse". A mountain in the back, in other words, should have a "descending aspect" to be assessed suitable as burial ground ${ }^{56}$.

The above rule "the tiger in the west is the corpse's path" means that the site is suitable for construction. But the following phrase "If bad water flows quickly in the middle of the path it becomes a 'tiger's corpse"' suggests that the place is unsuitable for a burial ground. Analogically, one could conclude that the meadow in the water is an obstruction of the dragon's power just as the bridge is. To my understanding, this reading is also applicable for the rule "a meadow and a rock in the middle of the grove are the corpse of the bird".

\section{The four animals on the move}

Despite their standard assignment to specific directions, the Tibetan tradition also sometimes moves the four animals around ${ }^{57}$. In the following passage, for example, Sangs rgyas rgya mtsho changes the traditional position of most of the four animals, such that it meets the description given in the Clear Mirror of Royal Genealogies. An animal in another direction conveys just another influence on the inhabitants. In whatever direction it is placed, its influence is usually positive. It is only the bird in the west that indicates a negative impact. He writes:

If at all the sites for [the erection of] houses and [the construction of] burial grounds the four deities of the directions are complete, this is good. That is to say: the path in the east is the whitish tiger, the water in the south is the dragon, the forest and marsh area in the west is the red bird. The rock face and marsh area (or meadow) in the north is the turtle. If this is all present, the population increases and [the inhabitants] gain yid tshang ${ }^{58}$. The tiger in the east is the rope that leads to wealth. The tiger in the south is the rope that leads to wealth. The dragon in the east [denotes] the gain of yid tshang and the dragon in the north is the water promoting wealth. The bird in the east is the tree that increases the population. The bird in the south is the mother of men, wealth and blessing. The bird in the west grasps the life force of men and horses. The turtle in the east takes hold of the population. The turtle in the west is the little bowl for life. The turtle in the north supports yid tshang ${ }^{59}$.

Without directly referring to a text, the astrologer dGe bkra pa of Derge monastery, one of my informants, explained the relation of the four animals to the directions and to certain topographical aspects as follows: the tiger symbolises the east, the path and the rock face; the dragon the south and the water, the bird symbolises the west and the forest and the turtle the north and a boulder. This corresponds to the order given in the text above. However, dGe bkra pa had studied the White Beryl and was also familiar 
with the rules regarding the "terrestrial antagonists" (sa dgra), a term denoting the shapes of places that are regarded as unsuitable for construction. A river in the east whose beginning and end is invisible during the sunshine, that is during daylight, is an unfavourable sign. To avoid damage, two water drinking yaks or 'bri should be led towards the sight of the river. Other unfavourable characteristics of the land are a cliff in the south or a mountain in the shape of a tooth. In these cases, damage was prevented by water: water from a pond a river or a waterfall should be filled into a vessel placed in the south ${ }^{60}$.

\section{The four animals inside the house}

51 The four animals are also connected with the interior of a house. Sangs rgyas rgya mtsho gives the following advice for the equipment of a house:

The four deities of the interior are good if they are as follows: [If] the manger for the cattle is in the east, the whitish tiger is positive. [If] the mill is in the south, the blue dragon is positive. [If] the fire place is in the west, the red bird is good. [If] the water vessel is in the north, the black turtle is positive ${ }^{61}$.

Another source for the four protectors and their relation to the interior of a building is Karma chags med's ${ }^{62}$ (1613-1678) geomantic advice that is found in the Advice for Mountain Retreats (Ri chos mtshams kyi zhal gdams). In a passage on the "site examination of the interior" (nang gi sa dpyad) he assigns the animals to directions in a different way from Sangs rgyas rgya mtsho, and he adds a fifth animal in the centre, the monkey. He writes:

Now to the site examination of the interior. The doors should be directed eastward, the lintel is the eastern tiger. The water vessel should be placed in the south; it is the blue turquoise dragon of the south. The fire place is in the west, it is the red bird. The mill should be erected in the north, it is the turtle. The golden monkey [should be placed] in the centre. The four protectors of the house are complete ${ }^{63}$.

The most striking figure here is the golden monkey. What is the origin of the monkey? It suggests the Tibetan myth of the monkey who - as either an incarnation of sPyan ras gzigs or at sPyan ras gzigs's command - united with a demoness (srin mo), who was later identified as sGrol ma. Their union produced the ancestors of the Tibetan people. The symbol of the monkey may also have come from China or from India. Could the monkey here be related to the Indian god Hanumān, who is usually depicted as a monkey? Or is it related to Guanyin, the Chinese version of sPyan ras gzigs, who is the monkey's protector? The five animals, including the monkey, also appear to be presented as "Lords of the ground" (sa bdag $\left.{ }^{64}\right)$.

\section{The four animals in other Tibetan traditions}

The constant change of the animals' directional assignment raises the question of how these animals are presented in other traditions. Or if there are other traditions associated with groups of animals. In Bon myth, for example, four animals protect the sacred mountain gYung drung: the garuda, tiger, dragon and yak, and each reigns over a direction. The yak replaced the turtle and in Buddhist iconography, the lion often replaces the yak ${ }^{65}$. The concept of protecting deities in the cardinal directions is similar to the Indian Buddhist concept of the four Lokapālas. 
55 In a fumigation offering to the local deities of the land, the Bonpos worship five animals. Among these, the lion replaces the yak, and the horse is added. The animals are, therefore, eagle, tiger, dragon, lion and horse. These five animals are connected with five aspects related to human lives in Chinese prognostic calculations: srog, lus, dbang thang, rlung rta and bla. The eagle or the garuda (bya khyung) symbolises the vital force (srog), the tiger symbolises the body (lus), the dragon prosperity (dbang thang), the lion good fortune (rlung $r t a$ ) and the horse symbolise the soul element (bla). As stated elsewhere, in the Bon tradition, the lion is the symbol for good fortune. Therefore, the horse had to be assigned to the soul element (bla).

In the fumigation offering, the animals are not directly placed in a direction but assigned a quality. Here, we also come across a lion with the turquoise mane.

In these rituals and ritual texts, the eagle (garuda) is addressed as the king of the birds, the subjugator of the three realms, who protects life by making it resemble the essence of the sky. The vermillion tiger, too strong and fearful to be defied by anyone, protects the body from harm by diseases by strengthening it like the wish fulfilling tree. The turquoise dragon, the lord of sound, protects wealth with its lightning and fills it like a lake in summer. The unrivalled white lion with the turquoise mane removes obstacles by creating good fortune as white as the snow mountain. And, finally, the horse magically gallops like the clouds that protects the soul (bla dpal) from being dispersed by the wind ${ }^{66}$.

This group of animals obviously originates in another tradition; they are not indigenous to Tibet. Where else are they found? The lion with the turquoise mane, for example is one of the four animals in the wedding songs of the Ladakhis. There, the four animals are: the white lioness with the turquoise mane (seng ge dkar mo g.yu ral pa can), the eagle, the king of the birds (bya rgyal rgod po), the striped Chinese or Indian tiger (rgya stag khra bo) and the fish with the golden eyes (nya mo gser mig). Most striking in this quartet are the fishes. They are also known as one of the eight auspicious symbols. In Hinduism, the two fishes symbolise the two rivers Gangā and Yamunā. In Buddhism, the golden fishes symbolise good fortune and spontaneous activity as they enjoy freedom of movement in water. There is also the possibility that the golden fishes are of Chinese origin. In China, they symbolise a couple's harmony, loyalty and abundance ${ }^{67}$. Fishes are a gift for weddings. They are related to the dragon that represents the scaly animals, i.e. the fishes. Like the dragon, they are often depicted in pairs $^{68}$. Another earlier source of the lion with turquoise mane is the Gesar epic. In this work, the eagle, dragon and lion represent the three clan lineages in the Gling community. A fourth animal, the tiger, is the symbol of Gesar's paternal uncle's lineage and is added to the initial three ${ }^{69}$.

Sangs rgyas rgya mtsho relates the lion, a white lion, with four other animals, to a prediction with regard to the topography of a certain place. The animals he evokes here are slightly different to the other presentation: they are the lion in the east, the turquoise dragon in the south, the turtle in the north and the peacock in the west. They symbolise positive places; in this set, the tiger, however, is lost:

The five areas, where the generations and the compensation payments due to murder multiply are like a white lion jumping into the sky from the peak of a big snow mountain in the east; or, like a turquoise dragon jumping into the sky from the peak of big snow mountain in the south; or else like a shining peacock jumping into the sky from the peak of a big snow mountain in the west or like the black turtle jumping into the sky from the peak of a big snow mountain in the north. Or, 
[the place looks] like a high throne in front [of the mountain], comfortable and separately placed ${ }^{70}$. eres wered by Buddhist deities in the mandala of the Five Transcendent Buddhas. In the mandala, the deities are assigned to the directions as follows: Amitābha is in the west, Ratnasambhava in the south, Amoghasiddhi in the north and Akșobhya in the east, Vairocana is assigned to the centre. The direction of Aksobya and Vairocana is not stable, and their position can be exchanged ${ }^{76}$. Like the animal deities, the Buddhas are related to the seasons, to the elements, to the five senses, to sounds, and to body parts; and they are endowed with certain qualities and powers. The deities also have their respective mounts: Vairocana rides a lion, Akșobhya an elephant, Ratnasambhava a horse, Amitābha a peacock and Amoghasiddhi a garuda or a dwarf ${ }^{77}$.

\section{The tiger as a sign of the zodiac}

The other symbolic meaning the tiger has in Chinese calculation (nag rtsis) and geomantic prognostication (sa dpyad) is as a sign of the zodiac. The zodiac signs are assigned to the cardinal and intermediate directions. Sangs rgyas rgya mtsho uses this 
assignment for a prediction with regard to construction without further explaining it. He states:

If wind comes from the direction of the two [animals] the tiger and the hare, from between two mountains, it is an area where sons and grandsons will often die of a violent death ${ }^{78}$.

Irrespective of the client's birth year or his or her specific element, which is called a rus chen $^{79}$, the topogaphic elements and natural phenomena like wind are thought to influence the construction depending on the direction from which they come. Only later on, Sangs rgyas rgya mtsho assigns the zodiac signs to the elements that determine their position in a certain direction:

With regard to the twelve-year-cycle of sky and earth, tiger and hare are the deities of [the element] wood. Horse and snake are the deities [of the element] fire. Bird and monkey are the deities ruling [the element] iron. Pig and rat are the deities [of the element] water. Dog, dragon, ox and sheep are the deities [of the element] earth ${ }^{80}$.

The assignment of the elements to them defines the position of the zodiac signs with respect to the directions. The tiger and hare are both assigned to the west as they are related to the wood-element. The horse and snake are assigned to the south, the bird and monkey to the east, the pig and rat to the north and the others to the intermediate directions.

\section{The tiger and shapes of land}

Prognosticators assess the topography of land as suitable and unsuitable for construction, before buildings are constructed. The assessment is completed using examples from living beings or any objects, be they religious symbols or from daily life. The main source I have found for this is chapter 32 of the White Beryl. Sangs rgyas rgya mtsho compiled the text from various manuscripts. He gives hardly any titles of these sources and a detailed analysis remains difficult. To make matters even more complicated, he composed the text in heptasyllabic metre, that is to say in sevensyllable lines. This leads to the omission of syllables. Tibetan words can be composed of one or more syllables. In order to create lines of seven syllables, sometimes the first, but more frequently the second syllable of a word is omitted. The verb can also be omitted, which causes problems for interpretation. Sangs rgyas rgya mtsho sometimes writes conditional clauses, but he does not use them consistently throughout this text. The phrases describing the places are, therefore, not uniformly structured. Despite the missing wording, however, the primary structure of the phrases referring to the consequences of topography suggests a conditional clause. It is appropriate to use the semiotic theory of protasis and apodosis to interpret these passages. This form of analysis suggests that these passages are saying: if the place looks like the tiger, its grinning face or its stripes and so on, it has such-and-such an effect ${ }^{81}$.

Sangs rgyas rgya mtsho structures the text on topography in passages that commonly resemble enumerative lists: first he describes a site's topography briefly by using an image, "hungry wolf", for example, and follows this with the consequence that this landform's presence will bring about. A rock like a hungry wolf brings "a chung sridemon". It suggests the place is considered a sa dgra, literally "terrestrial antagonist". Such places are unsuitable for the construction of buildings. He assesses places filled 
with Buddhist symbols as suitable for construction. If the sky has the eight spokes of the wheel, for example, the mountain on the right side resembles a haughty lion looking at the sky and the mountain at the left side resembles a raised chintz with the stripes of the tiger, then it is a good place to build ${ }^{82}$.

Such places are also suitable for certain activities or function as protection against damage. The topography can furthermore influence the stability of a building. Sangs rgyas rgya mtsho uses the tiger, its whole body or parts of it to describe topographic characteristics of the land that will perform these functions. Among the body parts of the tiger he uses to describe land forms are the tooth of a tiger (stag rgya so), its striped fur (gra' 'dzum), its raised head, its face, muzzle, goitre and its stomach fat.

In the following paragraph, I give a survey of the places that the author compares with the tiger or its body parts. He suggests that these topographical characteristics distinguish suitable and unsuitable sites for construction. The assessment of the quality of these places is not fixed: tiger places can be either good or bad. As related above, the Clear Mirror of Royal Genealogies suggests that two myths were combined to come up with these topographical readings: isomorphic mapping and the spatial order of the four cosmic animals from China.

\section{Negative tiger places}

\section{Tooth, head and mouth}

Places with pointed shapes are assessed as unsuitable. Mountains with pointed peaks are, of course, difficult to access. The images Sangs rgyas rgya mtsho uses to describe them are a raised tiger head, the tiger tooth, the open mouth and a fighting tiger. He explains:

[Places that look] like many teeth (so mangs, which could also be understood as comb), like the tooth of a saw, or like the tooth of an Indian tiger, are bad places comparable to inanimate [things] $]^{83}$.

The tooth's sharpness could symbolise some kind of danger threatening the inhabitants. However, this example depends for its description on the historical sources and at the same time contradicts them. There, Wencheng identifies the canine of the tiger, called mche, as the place to construct the sKyer chu lha khang in Bhutan ${ }^{84}$. The assessment of the tiger tooth as unsuitable could be connected to the concept of the pinning down of the demoness. 


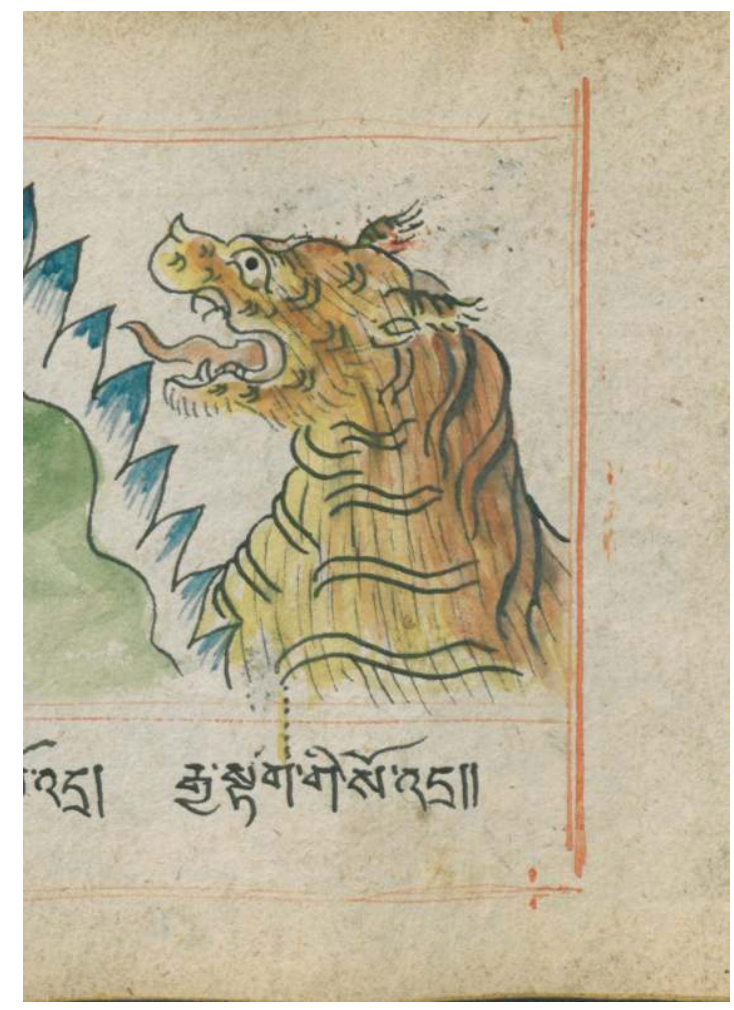

Bavarian State Library, Cod.tibet.896.

(C) Bavarian State Library

Likewise, Sangs rgyas rgya mtsho also considers mountain shapes identified as animal heads that might denote a certain thread unsuitable for constructions as they cause emigration, physical damage and arguments. He writes:

[If] rocky mountains [look like] the claw or the beak of a bird, the raised face of a camel, the raised face of lion, the raised head of a frog, the raised head of a turtle or the raised head of a tiger, people will emigrate. [In this area] cripples with damaged throats, limbs and sense organs and so on are found. Numerous diseases are also caused here [by the dysfunction] of the lymph ${ }^{85}$.

Another body part of the tiger that is assigned negative qualities is the tiger's mouth. The topographic characteristic called sa dgra are considered unsuitable:

[If the mountain resembles] the wide open mouth of the whitish tiger hit by a zor (a weapon that repels evil spirits ${ }^{86}$ ), then the acquisition of wealth is difficult and arguments are numerous ${ }^{87}$.

A tiger that bares its teeth appears threatening. In the following example, one could associate its open mouth with the idea of being swallowed, a frightening image that therefore qualifies the place as bad. The place the author describes now creates the idea of a very specific place and not a general statement:

In a ford, i.e. a passage - [the author inserts:] there is a settlement between the river and the cliff - is a settlement and in its surroundings, settlements have occurred crevices. [The place looks like] the gaping mouth of the whitish tiger - [he inserts:] between the paths are the villagers - and like the torn centre of a spot. These [characteristics] are a great sa dgra. They cause the occurence of hostilities against the king and the monastic community. Great fear arises here ${ }^{88}$. 


$$
\text { the mouth of a tiger brings poverty and childlessness. }
$$

\section{Fighting tiger}

The last example for an unsuitable shape associated with a tiger is a form that appears like a tigress fighting with a lion:

[If a boulder] resembles two people in an argument, and a lion fighting with a

tigeress ${ }^{89}$, [one averts a calamity] as before with a stone ${ }^{90}$.

Thatis to say, a gzungs or dhārañi (a ritual speech or spell, something like a mantra) should be written on a stone to prevent any damage.

\section{Positive tiger places}

\section{Grinning face, stripes and organs}

Places resembling the whole body of a tiger, its grinning face, its fur - or more precisely the stripes of its fur - the goitre and the belly fat are assessed as positive. Such places are suitable for construction. Sangs rgyas rgya mtsho writes:

Furthermore, these are the eighteen [places creating] the $d m u$ yab ${ }^{91}$ : [a place] that looks like it is besmeared with melted butter, the renal pelvis of an elephant ${ }^{92}$, the hollow organ of a sheep, the chest of a stag (brang zhol), the breast of a young woman, crossed arms, the grinning face of a tiger, a feed trough, porridge for children, heaped up jewels [and so on].

81 Although the meaning of the term dmu yab is not clear, it is listed among other positive effects on the inhabitants of a place.

The preceding passage decribes similar shapes:

[Places that look as if they are] besmeared with melted butter, the chest of a young woman, like the grinning face of a tigress [and so on], are the right places that create dmu yab $b^{93}$.

Generally, this passage however allows different interpretations. The Tibetan word 'dzum could be an abbreviation for gra 'dzum, the striped fur. As the examples and the resulting effects are almost identical with those given above, the interpretation "grinning face" is more likely to be correct. These repetitive examples indicate that Sangs rgyas rgya mtsho compiled the text and did not compose it.

\section{Stripes}

84 The most frequently applied example is the fur with its stripes. It provides protection from several threads and creates certain qualities. The two following passages, however, do not refer to a certain effect of such places and denote a suitable construction place in general. The first one reads:

[Places that look like] the hand of a goddess, the front part of the lower garment of a queen, the renal pelvis of an elephant, the mane of a lion, the heart of garuda, the striped fur and the face of a tigress [are suitable] for the construction [of buildings $]^{94}$.

And the second reads:

The mountain at the left side is like held-up cloth with tiger stripes. [The mountain on this side] is like a drawn curtain of white silk. The mountain on the other side 
(pha ri) is like a tent from heavy silk ( $z a^{\prime}$ og). The best place is the one that looks like a trough filled with liquid butter ${ }^{95}$.

\section{Achievement of certain qualities}

Then, Sangs rgyas rgya mtsho describes places connected with certain wishes and hopes or those that protect the inhabitants from any damage:

If one wants to construct a royal residence or if one wishes to have a hero as a son [one should built one's house] at a place resembling the heart of a king, the lap of a queen or the stripes of the tiger ${ }^{96}$.

Six [places] that block the spread of lung diseases (glo shar) ${ }^{97}$ and arguments with the family are like the cape (zla gam) of a minister, the glorious knot of a king, the striped fur of a tiger, the heart of an elephant, the knob of a vajra and the clapper (lce) of a bell ${ }^{98}$.

Moreover, a vey clear statement with regard to the quality of a place is given as follows:

[A place like] tiger fur is unconquerable. If one wishes [to be of] a noble character, one should construct [a building] there ${ }^{99}$.

\section{Figure 4. Place like a tiger fur}

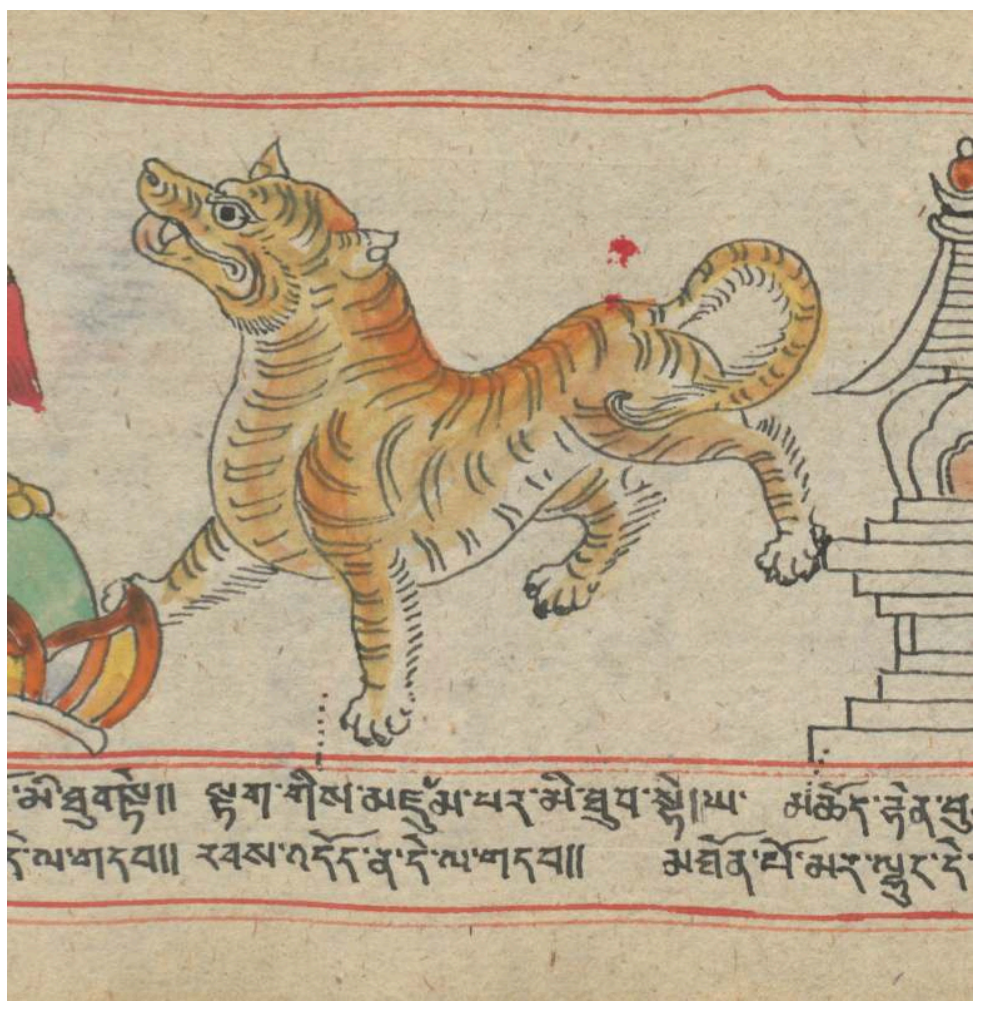

Bavarian State Library, Cod.tibet.896.

(C) Bavarian State Library

Lastly, it should be noted that tiger fur is also seen as a victory banner:

[Places resembling] a victory banner with a tiger, an ox or a man, a drop of blood or a drawing with fat [on the front] (zhag so) [belong to inanimate places] ${ }^{100}$.

In Tibetan concepts, the various influences from neighbouring countries are often hard to distinguish. The tiger fur's assessment as positive could be related to various concepts. It might relate to the Indian story of Śiva who wants to control his desires. He kills a tiger, a deed that symbolises that he subdued desires. Or else, the fur represents 
the powers assigned to a tiger, like strength and protection against several threads. Or else, it goes back to the Chinese concept from fengshui that interpretes certain shapes as a tiger - the shape resembles tiger fur ${ }^{101}$ - and assesses these as positive.

A boulder in the shape of a tiger is positive. The following place described by Sangs rgyas rgya mtsho sounds as if he had a specific place in mind. The details however are too vague to identify a specific place, especially when one does not know where to look for it:

At a place close by the house there is boulder. Even if it is split on its backside, it is good. A partially lying boulder is a door latch. Below it there is a boulder in the shape of a tiger. Close by the door [grows] a juniper tree, and in the east and the southeast is a lake. These are good [characteristics] ${ }^{102}$.

\section{Goitre and stomach fat}

91 Two other parts of the tiger are used as examples to define a place's shape: the goitre and stomach fat. These are not proper body parts, but if one looks at the face of the tiger, there is something similar to a goitre. The tiger's stomach fat is used in medicine to treat for example rheumatism, which might have influenced its positive assessment:

The six places where one becomes a hero are [places] that look like the chest of a lion, the goitre of a tiger, the renal pelvis of an elephant, the wings of a green falcon, a vulture strutting and puffing itself up (ham tshugs) and the chest of a man. The six places where the poor become rich [are places like] a circle, a swirl in the ocean, like brum rtse $e^{103}$, melted butter, pap, stomach fat of the tiger and like the renal pelvis of an $\mathrm{xx}^{104}$.

\section{Tiger and the stability of buildings}

Furthermore, the shape of a place or a mountain determines the stability of the buildings constructed there. The time spans given here for this stability are thirteen, nine, seven, six, five and two generations.

Sangs rgyas rgya mtsho identifies one mountain as "the king of the mountains": its appearance, which is described in detail, is said to be the best. If one constructs a building on it, the building will last for thirteen generations (rgyal ri mi rabs bcu gsum). This is the longest period of time mentioned in the chapter on sa dpyad. The shortest time span is two generations and is assigned to a building constructed in a place looking like a mandala. Places in the shape of a garuda or a lion last for only six or seven years (khyung seng drug bdun). His assessment of these places demonstrates once more the high esteem in which the tiger was held, along with the peacock. A building constructed at places with their shapes lasts for nine generations (stag dang rma bya mi rabs dgu), this is second only to the supreme mountain ${ }^{105}$.

Moreover, Sangs rgyas rgya mtsho distinguishes thirteen so-called inner and outer positive characteristics to use in sa dpyad. Besides various types of dwellings, these include such items as tents, monasteries, palaces, animals and so on. When they are grouped together in a set of two they define certain characteristics.

The thirteen inner characteristics [are as follows]: with birds on the snow mountain, a rocky mountain or a forested mountain, like a garuda and a vulture, it is one. With the carnivorous lion and tiger living there they are two. With the wild animals roaming around like stag and kyang, they are three. With the yak and the sheep herded on the upland pastures there are four. With the various water animals 
living in the water, like conches and crocodiles, there are five [inner positive characteristics]. With the group of properties like horse and ox there are $\operatorname{six}^{106}$.

\section{The tiger as an auspicious symbol in the ritual}

influence the inhabitants. Unfavourable constructions cause damage. Among these are, for example, the wrong orientation of the house itself, the unsuitable orientation of a corner to a staircase, or of a door to a corner, the door and the mill placed straight behind one another and so on. Such characteristics are classified as "the inner terrestrial antagonist" (nang gi sa dgra). Rituals will preserve the inhabitants from damage. Among the quite ordinary ritual activities are drawings at any parts of the building, for example at the door, the pillar or the wall. Another technique is to draw the symbol on paper or a piece of wood and to insert it between two beams. Tiger and lion are among the protective symbols. Another symbol is the jewel that is regarded as an auspicious sign. One ritual, for example, recommends drawing a tiger on a piece of wood and inserting the wood between the beams. Another ritual recommends drawing a tiger and lion as protection above the door or drawing a tiger and a jewel ${ }^{107}$.

More eleborate rituals are recommended as general protection when a house or a burial ground is constructed. The construction of a graveyard was, as in China, of major importance in Tibetan cultural areas, and special rules had to be followed when it was laid out. The rules included instructions for the positions in which the dead bodies needed to be placed, and the ritual protections necessary for the land.

\section{General protection of a construction site against terrestrial antagonists (sa dgra)}

97 As a general protection for the inhabitants and descendants against the terrestrial antangonists and the unsuitable topographical shapes, Sangs rgyas rgya mtsho describes the following ritual:

With regard to everything, [the construction] of a house, [the laying out of] a cemetery or [the tilling of] a field the following advice is important. Place a clay figure of a whitish tiger in the east, a figure of a blue dragon in the south, [a figure] of a red bird in the west and a figure of a black turtle in the north. On [a piece of] paper that is inserted in the middle of [each] body [write]: May all blessings and all virtues come together. May luck increase and may good reputations accumulate. [May] the earth, wood, water, rocks, a beacon (sgron $\left.{ }^{108}\right)$ and so forth, which is to say all noxious terrestial antangonists, be repelled by the whitish tiger from the eastern direction. [One] changes [the captions accordingly] and inserts [the piece of paper] in the respective [figures]. Furthermore, one inserts various ingredients [similar to those used for filling statues in these figures], such as medicine, grain, precious things, silk, the three sweet and three white ones and so on ${ }^{109}$.

This ritual resembles a gto ritual that 'Ju Mi pham rnam rgyal (1846-1912) describes in his Box of a Hundred Thousand Gto (gto sgrom 'bum tig). He calls it a "Treasure of the four protectors of the lord of the ground or of the four klung ${ }^{110 "}$ ( $s a$ bdag srung bzhi'am klung bzhi'i gter). The one who performs the ritual to protect the construction site should prepare clay figures of the four animal deities, fill them with grain and other blessed substances and conceal the figures in the following order: tiger in the east, dragon in the south, bird in the west and turtle in the north. The specific instruction here is that

Études mongoles et sibériennes, centrasiatiques et tibétaines, 50 | 2019 
the face of a dragon and a bird should point to the inside and the face of a tiger and a turtle to the outside ${ }^{111}$.

\section{Protection of a burial ground}

For the construction of a burial ground, Sangs rgyas rgya mtsho describes a specific ritual. In this ritual, the four animals, tiger, dragon, bird and turtle serve as the ground's protection. They are assigned to their original direction: the tiger in the west, the dragon in the east, the bird in the south and the turtle in the north. The monkey makes a return appearance here too; this time he is prepared from various metals and rides an animal. Sangs rgyas rgya mtsho writes:

For the outer protection of a burial ground, one needs the four deities. The protection in between is an old bluff. In the east, it is said, [the place should resemble] a little bird riding on a tiger. In the south, it is said, [the place] should [look like] a copper monkey riding on a dragon. In the west, it is said, it should [resemble] an iron monkey riding on a bird, and in the north it should [resemble] a golden monkey riding on a turtle ${ }^{112}$.

To my knowledge, there is no specific assignment of a certain metal to a direction. However, the idea would suit general Chinese concepts of prognostication quite well. One element that is quite striking about this ritual is the role of the golden monkey as a rider. We have already encountered the monkey as the animal in the interior of a building, where it was assigned to the middle, and here it is a rider. The presence of the monkey in both these situations raises questions that cannot yet be answered.

The four other animals also serve as protectors against unsuitable topographic characteristics:

In the north and the west one cuts off the path (rgyu srang) for the whitish tiger. Furthermore, one erects a khrom gnyer ${ }^{113}$ made of wood [towards the north and west]. [From] south to north one constructs a bridge for the green dragon. The turtle of the south has contracted [its head and limbs under its shell] and has concealed [itself] . The red bird of the north is pressed down by a boulder. A dried up tree, wherever it is, will be chopped. [Towards the mountain that looks] like a garuda [or] an ox, one shows [the image] of a lion. One points a mchod rten [towards the mountain that looks] like a lion. If there are many streams, earth fissures and cracks, one prepares many khrom gnyer ${ }^{114}$.

\section{The tiger meets Yul 'khor srung}

In my opinion, the most striking ritual is the following one, which is said to be performed when foundation stones are laid. Here, the four animals are addressed together with the four guardians of the cardinal directions. These guardians are of Indian origin. They each rule a group of goddesses or demons. The four animals are from Chinese cosmogony. Here they are all invoked and asked for protection.

King Yul 'khor srung (Skt. Dhṛtarāsțra) in the east rules the Dri za'i gdon. 'Phags skyes po (Skt. Virūdhaka) in the south rules the gShin rje'i gdon. King sPyan mi bzang (Skt. Virūpākșa) in the west rules the snake deities and the bdud demons. Finally, rNam thos sras (Skt. Vaiśravana) in the north rules the gnod sbyin. The kings and the animals are adressed together in their respective directions. They are endowed with certain powers and the tiger is obviously the most powerful one: 
"King of the east, Yul 'khor srung. I present you and the group of dri za demons this dough offering. I kindly request this place. Yul 'khor srung, king of the dri $z a$ demons, may you protect the teaching of the Buddha. Perform the activites of the Vajra family. Protect all those who are connected with the dri za in the east". One recites this and lifts a handful of white stones in the east, laying them down in the east. "From the east I invite the whitish tiger. I requested this place. May it grant custody to the donors. You are the goddess that increases the skilled and wise sons and grandsons, the horses, the yaks, cattle and the servants. Stay for a little while and support the construction. Ensure that the sa dgra in the four boundaries are conquered ${ }^{115}$ ". comes to mind, even though it is native to southeastern Tibet. As we have seen, however, the tiger is highly symbolic in various spheres of Tibetan culture, and was adapted and integrated into disciplines such as art, ritual practices and Chinese divination (nag rtsis). It is renowned particularly through its integration into art and ritual related to the construction of buildings and known as an attribute of yogins. The tiger became a part of Tibetan cultural and religious life. The symbolism was certainly strengthened by its significance in Indian and chinese culture. In Tibet and in China, the animal, its fat and its bones are used in traditional medicine. Likewise, as the mount of many deities, the tiger symbolises fearlessness and willpower. Considering its significance in rituals for the construction of buildings, the tiger seems to dominate the animal world. It resides over a spatial sphere but is installed as protector over the four directions. In a constellation with three or four animals, the tiger structures space and time. Together with other animals, it creates a spatiotemporal order. 
108 With regard to topography, the tiger is assessed as both negative and positive, depending on the circumstances. Some topographic characteristics that resemble its body parts seem to conjure negative consequences for a construction. But these occasional assessments do not mean that the tiger's symbolic presence is always negative.

109 Thus, there remains the open question of what Sangs rgyas rgya mtsho is referring to when he says in the beginning of his text that "the four deities are bad", a statement that obviously refers to some kind of bad quality or bad effect. This seems contradictory to their ritual function as protectors being adressed with the four rulers of the directions. This contradiction then leads to another question: why do Buddhist deities often ride animals? These animals are endowed with certain qualities that are somehow related to these deities. But usually, the deities and their mounts are regarded as separate entities. Does this mean something? And if so, what does it mean? Is his statement related to the animal's non-Buddhist symbolic origin? Did he know about these? These questions might not be answered but they deserve further reflection.

110 Mounting an animal and riding on it means that the rider has tamed and dominated the animal. By riding an animal the Buddhist deity is not only connected with the respective animal's power, but he or she also dominates the animal's power and adapts it. The Buddhist deities subdued and integrated these foreign and early forces into Buddhism; they tamed them. These depictions demonstrate their integration into Buddhism and Buddhist superiority. The Buddhist deities riding these animal deities symbolises their dominance over the old system. Therefore it seems very likely that Sangs rgyas rgya mtsho calls them "bad" because they were of non-Buddhist origin.

111 All this shows once more that the Chinese influences are much stronger in many fields of Tibetan knowledge and culture than has been assumed for a long time. These geomantic texts include concepts from at least India and China if not other parts of Central Asia. The ritual for the protection of a site that includes the Indian guardian deities and the four animal deities at the same time clearly demonstrates a complex integration and the combination of both cultures into one unit.

112 Even the ritual for the sa bdag, the lord of the ground, which I had assumed to be of Indian origin, could also be a Chinese concept, like the "duke of earth". His permanent position is in the middle, but he travels on earth. The depiction here is from an almanac; the heavenly stems and earthly branches are combined in a cycle of 60 days ${ }^{117}$. 
Figure 5. Duke of Earth in periodical motion

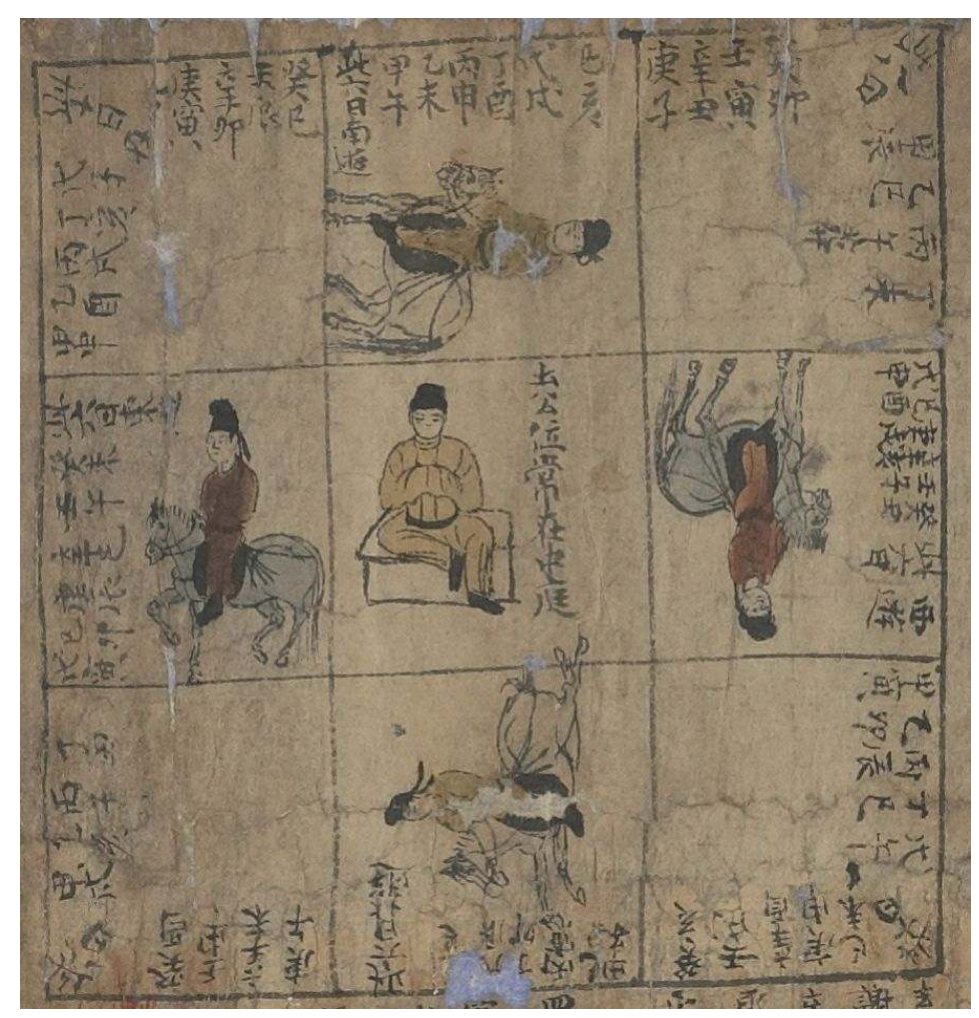

(c) source gallica.bnf.fr, Bibliothèque nationale de France

113 With regard to traditions and their transmissions - and this is also well known from Tibetan medicine - Tibet was a melting pot with influences from as far afield as Greece. Although Buddhism came from India, Chinese influences on Tibetan culture are equally significant. Tibetans integrated many elements of the other cultures they encountered. They show a surprising ease in combining different traditions, especially the idea of the demoness, the Buddha with the four animal deities, and the ritual performed when the foundation stone of a building is laid. This becomes very obvious in the written tradition: in the lineage of transmissions of texts on nag rtsis, Chinese divination, Tibetans include Kong tse or Confucius but also the Hindu deity Brahmā as those who were taught nag rtsis by Mañjuśrīi118.

\section{BIBLIOGRAPHY}

Akasoy, A., C. Burnett \& R. Yoeli-Tlalim (eds) 2016 Islam and Tibet. Interactions along the Musk Routes (London/New York, Routlege).

Aris, M. 1979 Bhutan. The Early History of a Himalayan Kingdom (Warminster, Aris and Phillips).

Asim, I. 1993 Religiöse Landverträge aus der Song-Zeit (Heidelberg, Ed. Forum). 
Baumann, B. 2008 Divine Knowlege. Buddhist Mathematics According to the Anonymous Manual of Mongolian Astrology and Divination (Leiden/Boston, Brill).

Beckwith, C. L. [1987] 1993 The Tibetan Empire in Central Asia (Princeton, Princeton University Press).

Beer, R. 2003 Die Symbole des Tibetischen Buddhismus (Munich, Diederichs).

Beijing daxue chutu wenxian yanjiusuo [Institut für Ausgrabungstexte der Peking Universität] (eds) 2014 Beijing daxue cang Xi Han zhujian [Bambusstreifen der West Han-Zeit, welche die PekingUniversität aufbewahrt], vol. 5 (Shanghai, Shanghai guji).

Boord, M. J. 1993 The Cult of the Deity Vajrakila. According to the Texts of the Northern Treasures Tradition of Tibet (Tring, U.K., The Institute of Buddhist Studies).

Cammann, Sch. 1961 The magic square of three in Old Chinese philosophy and religion, History of Religion 1, pp. 37-80.

Chen, C. 1989 Chinese Symbolism Among the Huns, in K. Sagaster (ed.), in collaboration with H. Eimer, Religious and Lay Symbolism in the Altaic World and Other Papers. Proceedings of the $27^{\text {th }}$ Meeting of the Permanent International Altaistic Conference, Walberberg, Federal Republic of Germany June $12^{\text {th }}$ to $17^{\text {th }} 1984$ (Wiesbaden, Otto Harrassowitz), pp. 62-70.

dPag bsam ljon shing: see lHa mo tshul khrims.

Eberhard, W. 1983 A Dictionary of Chinese Symbols. Hidden Symbols in Chinese Life and Thought (London/New York, Routledge).

Fahd, T. 2012 Khațt, in P. Bearman, Th. Bianquis, C. E. Bosworth, E. van Donzel \& W. P. Heinrichs (eds) Encyclopaedia of Islam, second edition [online, URL: http://dx.doi.org/ 10.1163/1573-3912_islam_SIM_4237 accessed 11 April 2018].

Feuchtwang, St. 1974 An Anthropological Analysis of Chinese Geomancy (Vientiane, Éditions Vithagna).

Granet, M. 1997 Das chinesische Denken. Inhalt - Form - Charakter (Frankfurt, Suhrkamp).

Gyatso, J. 1987 Down with the demoness. Reflections on a feminine ground in Tibet, The Tibet Journal 12(4), pp. 38-53.

Gyurme Dorje 2001 Tibetan Elemental Divination Paintings. Illuminated manuscripts from the White Beryl of Sangs-rgyas rGya-mtsho with the Moonbeams Treatise of Lo-chen Dharmaśri (London, John Eskenazi Ltd.).

Harva, U. 1938 Die religiösen Vorstellungen der altaischen Völker (Helsinki, Suomalainen tiedeakatemia).

Hoffmann, H. 1975 Tibet. A Handbook, in collaboration with S. Frye, T. J. Norbu, Ho-chin Yang (Bloomington, Research Centre for the Language Sciences).

Kong sprul blo gros mtha' yas 1975-1976 Tsi na'i sa dpyad gsar 'gyur lugs kyi sgo 'byed 'phrul gyi lde'u mig [The magical key that opens the door to the new tradition of Chinese geomancy], in bKa' mdzod, vol. Ta.

lHa mo tshul khrims (ed.) 2000 Nag rtsis rdel 'grem 'bras bshad dpag bsam ljon shing zhes bya ba bzhugs so [The wishfulfilling tree that explains the results of spreading the pebbles in Chinese calculation] (Dharamsala, Bod gzhung sman rtsis khang).

Karmay, S. G. 1998 The Arrow and the Spindle. Studies in History, Myths, Rituals and Beliefs in Tibet (Kathmandu, Mandala Book Point). 
Karmay, S. \& Yasuhiko Nagano (eds) 2003 A Survey of Bonpo Monasteries and Temples in Tibet and the Himalaya (Osaka, National Museum of Ethnology).

Laufer, B. 1912 Fish Symbols in China, The Open Court 1912(11), pp. 673-680 [online, URL: http:// opensiuc.lib.siu.edu/cgi/viewcontent.cgi?article=2706\&context=ocj, accessed 18 February 2019].

Lavizzari-Raeuber, A. 1984 Thangkas. Rollbilder aus dem tibetischen Himalaya. Kunst und mystische Bedeutung (Köln, Dumont Verlag).

Lin, S. 2005 Mi pham's Systematisierung von gTo-Ritualen (Halle, International Institute for Tibetan and Buddhist Studies).

Manetti, G. 1993 Theories of the Sign in Classical Antiquity, translated by C. Richardson. (Bloomington/ Indianapolis, Indiana University Press).

Maurer, P. 2009 Die Grundlagen der tibetischen Geomantie dargestellt anhand des 32. Kapitels des Vaidūrya dkar po von sde srid Sangs rgyas rgya mtsho (1653-1705) (Halle, International Institute for Tibetan and Buddhist Studies).

2012 Sa dpyad and the concept of bla ri, in C. Ramble \& J. Sudbury (eds), This World and the Next. Contributions on Tibetan Religion, Science and Society (Andiast, International Institute for Tibetan and Buddhist Studies GmbH), pp. 67-69.

2012-2013 Ein Thangka zur sino-tibetischen Divination, Münchner Beiträge zur Völkerkunde 15, pp. 218-243.

Maurer, P. \& M. Kretschmar 2006 Tür-Rundbehänge aus Tigerteppichen (Paar), in Tibet. Klöster öffnen ihre Schatzkammern (München, Hirmer Verlag), pp. 52-553.

Men-Tsee-Khang 2008 bBud rtsi snyin po yan lag brgyad pa gsang ba man ngag gi rgyud las rtsa ba'i rgyud dang bshad pa'i rgyud ces bya. The Basic Tantras and the Explanatory Tantra from the Secret Quintessential Instructions on the Eight Branches of the Ambrosia Essence Tantra (Dharamsala, MenTsee-Khang Publications).

Meyer, F \& C. Jest 1987 Milieux, Matériaux et Techniques, in P. M. Vergara \& G. Béguin (eds) Demeures des Hommes, Sanctuaires des Dieux (Roma/Paris, Universita di Roma/Réunion des musées nationaux), pp. 146-167.

mKhas grub Karma chags med 2010 Sa dpyad rin chen gter mdzod [The precious treasury of gemonancy], in mKhas grub Karma chags med, mKhas grub Karma chags med kyi gsung 'bum, vol. 58 (Nang chen rdzong, gNas mdo gsang sngags chos 'phel gling gi dpe rnying nyams gso khang), pp. 175-186.

Monier-Williams, Sir M. [1899] 1986 A Sanskrit-English Dictionary. Etymologically and Philologically Arranged with Special Reference to Cognate Indo-European Languages (New Delhi, Motilal Barnasidass).

Nebesky-Wojkowitz, R. de [1956] 1993 Oracles and Demons of Tibet. The Cult and Iconography of the Tibetan Protective Deities (Kathmandu, Tiwari's Pilgrims Book House).

Namkhai Norbu 1997 Drung, Deu and Bon. Narrations, Symbolic Languages and the Bön Tradition in Ancient Tibet (Dharamsala, Library of Tibetan Works and Archives).

Nowotny, K. A. 1967 (ed.) Henricus Cornelius Agrippa ab Nettesheym. De occulta philosophia (Graz, Akad. Druck- u. Verlagsanstalt).

Paton, M. J. 2013 Five Classics of Fengshui. Chinese Spiritual Geography in Historical and Environmental Perspective (Leiden, Brill). 
Pelliot chinois 2964, in Gallica (Paris, Bibliothèque Nationale de France) [online, URL: https:// gallica.bnf.fr/ark:/12148/btv1b8302295m/f3.image.r=pelliot\%20chinois\%202964, accessed 8 February 2018].

Pingree, D. 1981 Jyotiḥ̄astra. Astral and Mathematical Literature (Wiesbaden, Otto Harrasowitz).

Sangs rgyas rgya mtsho 1997 Phug lugs rtsis kyi legs bshad bai dūrya dkar po [The elegant sayings on calculation according to the system of the Phug-pa-School], vols 1-2 (Pe cin, Krung go'i bod rig pa dpe skrun khang).

Raphals, L. 2013 Divination and Prediction in Early China and Ancient Greece (Cambridge, University Press).

Savage-Smith, E. \& M. B. Smith 2004 Islamic geomancy and a thirteenth-century divinatory device. Another look, in E. Savage-Smith (ed.), Magic and Divination in Early Islam (Aldershot, U.K., Ashgate/Variorum), pp. 211-276.

Schwieger, P. 1978 Ein tibetisches Wunschgebet in der Sukhāvatī (St. Augustin, VGH Wissenschaftsverlag).

Shen, W. 2002 Leben und historische Bedeutung des ersten Dalai Lama dGe 'dun grub pa dpal bzang po (1391-1474). Ein Beitrag zur Geschichte der dGe lugs pa-Schule und der Institution der Dalai Lamas (St. Augustin, Institut Monumenta Serica).

Skinner, St. 1982 The Living Earth Manual of Feng-Shui (London/Boston/Melbourne/Henley, Routledge \& Keagan Paul).

Smith, A. K. 2011 Remarks concerning the methodology and symbolism of Bon pebble divination, Études mongoles \& sibériennes, centrasiatiques \&tibétaines 42, pp. 2-15.

Sørensen, P. 1994 Tibetan Buddhist Historiography. The Mirror Illuminating the Royal Genealogies. An Annotated Translation of the XIV ${ }^{\text {th }}$ Century Tibetan Chronicle: rGyal-rabs gsal-ba'i me-long (Wiesbaden, Harrassowitz Verlag).

Sørensen, P. \& G. Hazod 2005 Thundering Falcon. An Inquiry into the History and Cult of Khra-'brug, Tibet's First Buddhist Temple (Wien, Österreichische Akademie der Wissenschaften).

Thompson, L. G. 1969 Chinese Religion. An Introduction (Belmont, Dickenson).

Thubten Legshay Gyatsho 1979 Gateway to the Temple. Manual of Tibetan Monastic Customs, Art, Building and Celebrations (Kathmandu, Ratna Pustak Bhandar).

Tseng, T. 2005 Sino-tibetische Divinationskalkulationen (Nag rtis). Dargestellt anhand des Werkes dPagbsam ljon-shing von Blo bzang tshul khrims rgya mtsho (Halle, International Institute for Tibetan and Buddhist Studies).

Tucci, G. 1949 Tibetan Painted Scrolls, vols 1-2 (Roma, La Libreria Dello Stato).

Vernes, K. \& R. Rajaratnam 2012 Tall tales misrepresent the real story behind Bhutan's high altitude tigers, The Conversation [online, URL: http://theconversation.com/tall-talesmisrepresent-the-real-story-behind-bhutans-high-altitude-tigers-8963, accessed 26 July 2017].

Xiaochun, S. \& J. Kistemaker 1997 The Chinese Sky During the Han. Constellation Stars and Society (Leiden/New York/Cologne, Brill).

Yang, X. (ed.) 2004 New Perspectives on China's Past. Chinese Archaeology in the Twentieth Century, vols 1-2 (New Haven and London, Yale University Press).

Zhang, J. 2004 A Translation of the Ancient Chinese "The Book of Burial (Zang shu) by Guo Pu (276-324)" (New York and Ontario, The Edwin Mellen Press). 


\section{NOTES}

1. See Vernes \& Rajaratnam 2012.

2. The research on which this article is based is drawn from my habilitation on Tibetan Geomancy. I would like to thank the International Consortium for Research in the Humanities, "Fate, Freedom and Prognostication: Strategies for Coping with the Future in East Asia and Europe", at the University of Erlangen-Nuremberg, for generously funding my visiting fellowship that allowed further research on this subject. Furthermore, I would like to thank Ruth Gamble, La Trobe University, and the two anonymous reviewers of this article for their suggestions and comments.

3. The system of mathematics, astronomy and astrology introduced from India is called skar rtsis.

4. The "School of the Compass" calculates the places by the elements, the trigrams, the position of stars and so on. For the symbols used in the compass, see Feuchtwang 1974, pp. $16 \mathrm{ff}$.

5. Manetti 1993, pp. 6-8.

6. Prognostication can be understood as the assessment or the act of making an assessment or judgement about what is likely to happen in the future. In medicine, a prognostication denotes what is the likely or expected development of a disease.

7. For further details, see Savage-Smith \& Smith 2004.

8. Other terms are dili 地理 (shape of the land) or kanyu 看域 (examination of ground).

9. See Smith 2011.

10. See Fahd 2012.

11. See Pingree 1981, p. 79.

12. See Monier-Williams 1986, p. 686. Both types of divination, geomancy and the art of dotting (Punktierkunst) spread in different areas of the world, the art of dotting mainly in Europe and in Arab countries as far as Africa, and geomancy in Asia. The art of dotting called raml was systematized around the $8^{\text {th }} / 9^{\text {th }}$ century when Arabic culture was flourishing and spread together with Islam to Africa, Byzantium and to Spain. There it formed the basis for the art of dotting in Europe.

13. See Nowotny 1967 , pp. $202 f$. and 449.

14. For a study on the interactions between Islam and Tibet, see Akasoy et al. 2011.

15. For more details of the story see Aris 1979, pp. 3, 13, Sørensen 1994, pp. 253f, Sørensen \& Hazod 2005, pp.171ff, and Maurer 2009, pp.45f. According to Beckwith [1987] 1993, p. 24, Wencheng is said to have left for Tibet on March 2 in 641 escorted by a Chinese prince and a Tibetan minister. Other sources report that she had taken with her a divination chart (gab tse) from the emperor Taizong, and used it to calculate suitable places for the construction of buildings, especially temples and monasteries.

16. Sørensen 1994, p. 153, see Tseng 2005, pp. 61.

17. Karmay \& Nagano 2003, pp. 70-71.

18. See Hoffmann 1975, p. 108 and Gyatso 1987, p. 49.

19. Maurer 2009, p 301. The astrologer dGe bkra pa, whom I met in 2001 in Derge, told me another concept that relates only to China and Tibet. The dragon symbolises these two countries: China is the head and Tibet is the tail.

20. The tiger is the national animal of Bangladesh, India, Malaysia and South Korea.

21. Men-Tsee-Khang 2008, p. 218. See also Beer 2003, pp. 98-99.

22. Maurer \& Kretschmar 2006, pp. 552-553.

23. Usually graves are constructed as permanent buildings; an unsuitable place can however disturb the $q i$, which might vanish from the place. If a diviner diagnoses the loss of $q i$, the grave can be moved to another place. If the relatives ignore this advice, damage might follow; see Asim 1993, p. 84.

24. See Yang 2004, pp. 53-54, Xiaochun \& Kistemaker 1997, pp. 115-118. 
25. Beijing daxue chutu wenxian yanjiusuo 2014, p. 42. I would like to thank Constanze Cook, University of California, for providing me this reference. According to Hans van Ess, LMU Munich, there are however some doubts about the provenance of these documents that were found in the antiques market in Hongkong.

26. For the terms yin and yang see for example Granet 1997, p. 254.

27. See for example Skinner 1982, pp. 3f. and Feuchtwang 1974, pp. $157 \mathrm{ff}$.

28. Skinner 1982, p. 14, claims a similar concept for $q i$ and Hebrew ruach. Daoism distinguishes certain types of $q$ i.

29. Interestingly, Tibetan geomantic text do not mention $q i$ or introduce this concept. The fact that qi pervades everything might have led to this silence. The Chinese concept of qi could be related to the Tibetan idea of a bla gnas, a vital force pervading the land and often especially related to mountain cults.

30. See Skinner 1982, pp. $23 \mathrm{ff}$.

31. Asim 1993, p. 78.

32. See Skinner 1982, pp. 64ff.

33. See Granet 1997, pp. 136ff., Cammann 1961, p. 37.

34. For the various orders of the spar kha and their assignments to other dimensions, see for example Feuchtwang 1974, pp. 73-80, Granet 1997, pp. 137f. and Raphals 2013, p. 341. The spar kha are arranged in an octagon; the number five that is related to the centre is therefore missing.

35. The Chinese term wuxing 五行 is rendered by agents or elements. The frequent translation as "phases" is derived from the German word Wandlungsphasen, created by Porkert in his work "Die chinesische Medizin". The term "phases" or Wandlungsphasen, however, neclects a stable stubstance which, according to Marc Kalinowski (personal communication at the IKGF in Erlangen in July 2017), has to be assumed for the concept of wuxing.

36. In Greek and Indian concepts, wood and iron are not regarded as elements, instead "air" was included.

37. See Paton 2013, p. 289.

38. See Paton 2013, p. 70. For a translation of the Book of Burial, see Zhang 2004. On the four animals see especially Zhang 2004, pp. 121-130.

39. On their development, see also Xiaochun \& Kistemaker 1997, pp. 116-118.

40. See Feuchtwang 1974, pp. 151-158.

41. The so-called "School of the Compass" influenced the calculation of the right place in Tibetan sa dpyad.

42. See Feuchtwang 1974, pp. 157-158.

43. Zhang 2004, p. 121.

44. The Huns, for example, are said to have used the colours of the agents and symbols of the four animals in warfare when they arranged their troops in the various directions, see Chen 1989 , pp. 63-67.

45. The four animals were also adopted in Mongolian divination where the red bird that turned into a magpie is of a major significance in calculation; see Baumann 2008, p.117. Animals assigned to the directions of the sky are found in other cultures as well; see Harva 1938, p. 87.

46. For a survey on the contents, see Maurer 2009, pp. 71-72.

47. See Uebach 1987, pp. 90-91.

48. The relations are found in the rGyal rabs gsal ba'i me long; see Sørensen 1994, pp. 260-261, in the Mani bka' 'bum; see Aris 1979, p. 21; and also in the Gateway to the Temple; see Thubten Legshay Gyatsho 1979, p. 29.

49. Maurer 2009, p. 169.

50. $n e^{\prime} u$ is an abbreviation for ne'u gsing or ne'u gseng. Norbu 1997, p. 131, translates ne'u seng as "marshy meadow". 
51. The term dben rtsa is not clear. Its general meaning as "retired" or "solitary" does not apply here. As the turtle is identified as meadow, we may wonder whether it is supposed to be in the meadow, and might therefore denote a certain kind of grass.

52. dgu pa lam po stag skya yin/chu ni 'brug la na chal (r. nags tshal) bya / brag dang ne'u rus sbal yin / de yang nub stag ro lam yin / byang ni dgra yi zhon rta yin / byang gi bya ni than bya nyid / dgra rgol zhes bya ngan pa'o / phyogs su lha bzhi tshang gyur kyang/stag dgra shva dang ri sna zug / 'brug dgra chu la zam pa btsugs / bya dgra ldebs dang lam gyis chod / rus dgra phug dang dben rtsa yod / lha bzhi dgra zug ngan par bshad //, see Sangs rgyas rgya mtsho 1997, smad cha, p. 246.2-4. For the German translation, see Maurer 2009, p. 183.

53. tshal na is interpreted as nags tshal.

54. Tibetan diviners interpreted these passages as rules for the construction of a burial ground that depend on the element of the dead person and the environment.

55. lam dbus chu ngan shar shar 'bebs / de nyid stag gi ro khur yin / chu dkyil ne'u sa chags na / 'brug gi\{s\} ro khur tshal na'i dkyil / ne'u brag yong (r. yod) byas ( $r$. bya'i) ro khur / ne'u'i khar ni lam 'go chad / na kha mtha' med lam 'go chad / brag steng sdong po rtse chad dang / shing ral (r. rul) mgo zlum yod pa na / byang gi rus sbal ro khur yin/ro khur de dag shin tu ngan/shar du ri che byang gnam che / nub tu thang che byung na ngan //, see Sangs rgyas rgya mtsho 1997, smad cha, p. 246.4-8. For the German translation, see Maurer 2009, p. 183.

56. Zhang 2004, p. 127.

57. In the Chinese tradition they can also be assigned to various directions; see for example Paton 2013, p. 113.

58. The term yid tshang is not clear. Gyurme Dorje 2001, p. 159 proposes "reputation", probably derived from yid tshang grags.

59. khang sa dur sa thams cad la / phyogs kyi lha bzhi tshang ba bzang/de yang shar gyi stag skya bo / lam yin lho chu 'brug tu shes / nub kyi bya dmar tshal dang na / byang gyi rus sbal brag dang na / mi grangs 'phel zhing yid tshang thob / shar gyi stag ni dpal'dren thag / lho stag dpal gyi sna thag yin / shar 'brug yid tshang thob pa dang/byang 'brug dpal gyi bskul chu yin/shar bya mi grangs 'phel shing yin / lho bya mi nor g.yang gi ma / nub bya mi rta'i tshe srog 'dzin / shar gyi rus sbal mi grangs 'dzin / nub kyi rus sbal tshe'i par bu / byang gi rus sbal yid tshang brten //, see Sangs rgyas rgya mtsho 1997, smad cha, p. 264.27-265.4. For the German translation, see Maurer 2009, p. 232.

60. Personal communication in Derge in 2003.

61. nang gi lha bzhi 'di ltar bzang / shar du phyugs bres stag skya bzang / lho ru rang 'thag 'brug sngon bzang/nub tu thab bcas bya dmar dge/byang du chu snod rus sbal bzang/, see Sangs rgyas rgya mtsho 1997, smad cha, p. 265.4-6. For the German translation, see Maurer 2009, p. 232. The mill is certainly a watermill.

62. For his person, see Schwieger 1978, pp. 37ff.

63. de nas nang gi sa dpyad ni / sgo ni shar du btsug pa yi / sgo them shar gyi stag skya bo /chu ra lho ru bzhag pa yi / lho yi g.yu 'brug sngon mo yin / thab kha nub bcas bya dmar mo / rang thag byang btsug rus sbal yin / dkyil ka dbus kyi gser sbrel te / khyim gyi srung bzhi tshang ba yin //, mKhas grub Karma chags med 1961, p. 218.

64. See Nebesky-Wojkowitz [1956] 1993, p. 292 and Feuchtwang 1974, p. 170.

65. See Tucci 1949, p. 719.

66. Karmay 1998, p. 255.

67. See Tucci 1949, p. 719.

68. On the fish as a Chinese symbol; see Laufer 1912; Beer 2003, p. 22.

69. See Karmay 1998, p. 421.

70. mi rabs mi stongs 'phel sa lnga/shar phyogs gangs chen rtse mo la/seng dkar gnam la mchong 'dra (1) dang / lho phyogs gangs chen rtse mo la / g.yu 'brug gnam la mchong 'dra (2) dang / nub phyogs gangs chen rtse mo la / mdangs ldan rma bya gnam mchong (3) 'dra / byang phyogs gangs chen rtse mo la / rus sbal nag po gnam mchong 'dra (4) / mdun du khri 'phangs bde zhing khud (5) //, see Sangs rgyas 
rgya mtsho 1997, smad cha, p. 268.21-24. For the German translation, see Maurer 2009, p. 243. The translation of this last phrase is tentative.

71. Feuchtwang 1974, p. 154.

72. The peacock, that is believed to render poison harmless, was declared the country's national bird in 1963.

73. Eberhard 1986, p 229.

74. Karmay 1998, p 413.

75. See Karmay 1998, pp. 418-420.

76. Beer 2003, pp. 328-329.

77. Lavizzarri-Raeuber 1984, pp. 20, 125-129.

78. stag yos gnyis kyi phyogs dag nas / ri bar dong nas rlun byung na / bu tsha grir shi mang ba'i sa /, see Sangs rgyas rgya mtsho 1997, smad cha, p. 243.3-4. For the German translation, see Maurer 2009, p. 174.

79. For the term rus chen see chapter 22 of the Vaidūrya dkar po, tshe rabs las rtsis kyi skor; see Sangs rgyas rgya mtsho 1997, stod cha, p. 259.14: de yang khams la lnga yin te / keg shing ji me kungs sa dang / shang lcags ' $u$ chu rus chen lnga //, they correspond to the five tones in Chinese music.

80. gnam sa'i lo 'gros bcu gnyis ni / stag dang yos bu shing gi lha / rta sbrul me lha bya sprel gnyis / lcags la dbang sgyur byed pa'i lha / phag dang byi ba chu yi lha / khyi 'brug glang lug sa yi lha / sku mdog cha lugs so sor ston/, see Sangs rgyas rgya mtsho 1997, smad cha, p.291.28-29. For the German translation, see Maurer 2009, p. 304. See also Tseng 2005, p. 68.

81. Manetti 1993, pp. 6-8.

82. Maurer 2009, p 219.

83. som ngas (r. so mangs) 'dra / sog le'i so dang rgya stag so / phag brkos dred brad 'dra ba dang / sdong rgan bsgyel ba 'dra ba dang/lcags sgrog lag sgrog sga yi dbyibs/brub khung lcags thab rdza sol phung / khog stong yas khung 'dra ba rnams / srog med 'dra ba'i sa ngan yin //, see Sangs rgyas rgya mtsho 1997, smad cha, p. 249.19-21. For the German translation, see Maurer 2009, pp. 192-193.

84. See Uebach 1987, pp. 91.

85. ri brag bya yi mchu sder 'dra / rnga mo gdong zug 'dra ba'am / seng ge'i gdong pa 'dra ba'am / sbal mgo rus sbal gdong 'dra ba / stag gi mgo 'dra ba rnams zug / mi rnams kyang ni yul yang 'pho / 'phye bo ske mjing yan lag dang / dbang po la sogs skyon can 'ong / chu ser nad ni mang ba 'byung/, see Sangs rgyas rgya mtsho 1997, smad cha, p. 250.26-28. For the German translation, see Maurer 2009, p. 195.

86. See for example Norbu 1997, p. 281, footnote 16 and Nebesky-Wojkowitz [1956] 1993, pp. 354-358, 496-499.

87. stag skya kha gdangs zor gzhu 'dras / longs spyod sgrub dka' rtsod mang zhing / tha mar myur du 'jig 'gyur bas / glang chen sha chen rta rus la / stobs po che yi gzugs bris nas/, see Sangs rgyas rgya mtsho 1997, smad cha, p. 254.19-21. For the German translation, see Maurer 2009, p. 203.

88. rab so ('dir chu brag bar na grong yod kyang) dag na grong yod dang / sa ral grong gi mtha' bskor byung / stag skya (lam kha dbrag bar na grong pa) kha gdangs 'dra ba dang / sa yi gzhung ral 'dra ba dag / 'di rnams sa dgra chen po ste / rgyal po dang ni dge 'dun sde / dgrar ldang ma byas 'jigs chen 'ong /, see Sangs rgyas rgya mtsho 1997, smad cha, p. 252.22-25. For the German translation, see Maurer 2009, p. 199.

89. The term bya khrid is most probably a phonetic transcription of Sanskrit vyāghrī, that means "tigress".

90. mi gnyis gshags 'gyed 'dra ba dang / seng ge bya khrid 'thab 'dra dang / de dag rdo la snga ma bzhin /, see Sangs rgyas rgya mtsho 1997, smad cha, p. 253.28-254.1. For the German translation, see Maurer 2009, p. 201.

91. The meaning of $d m u$ yab is unclear. The explanation given by L.S. Dagyab, that it is synomymous with $d m u$ gab, a term supposed to denote the incapability of any kind of intellectual activity is not really convincing as the place is assessed as positive. 
92. Shen 2002, p. 216.

93. mar khu bskus pa lta bu dang / na chung nu ma lta bu dang ... stag mo'i 'dzum ... dmu yab bskyed pa'i sa brgyad yin / Here follows the passage translated above: gzhan yang dmu yab bco brgyad ces / mar khu bskus 'dra glang chen gyi / mkhal khung lug gi don mkhal 'dra / sha pho'i brang zhol na chung gi / nu 'dra phyag rgya bsnol ba dang/stag gi 'dzum mdangs mtshul pa 'dra/zhag gzhong mar khu'i u skyu dang / nor bu rin chen pho tshom spungs //, see Sangs rgyas rgya mtsho 1997, smad cha, p. 266.2-7. For the German translation, see Maurer 2009, pp. 235-236. The term na chung, here translated as "the chest of a young woman" could also be understood more generellay as "the chest of a young person".

94. Iha'i lag btsun mo'i mdun gsham la / glang chen mkhal khung seng ge'i ral / khyung thugs stag mo'i gra 'dzum dang/gdong gdab/, see Sangs rgyas rgya mtsho 1997, smad cha, p. 266.26-27. For the German translation, see Maurer 2009, p. 238.

95. g. yon ri stag ras bzed pa 'dra / dar dkar yol ba brkyang 'dra ba / pha ri za 'og gur khyim 'dra / mar khu gzhong par 'khyil 'dra'i sa / mchog yin/, see Sangs rgyas rgya mtsho 1997, smad cha, p. 261.11-12. For the German translation, see Maurer 2009, p. 219.

96. rgyal sa dpa' bo bu 'dod na / rgyal thugs btsun bang (r. pang) stag 'dzum la /, see Sangs rgyas rgya mtsho 1997, smad cha, p. 267.7. For the German translation, see Maurer 2009, p. 239.

97. Translation of glo shar according to the astrologers bSod nam rdo rje and Kun dga' rin chen, personal communication.

98. blo (r. glo) shar dme 'phro gcod pa drug / blon po'i zla gam (1) rgyal po yi / dpal be (2) stag 'dzum (3) glang chen snying (4)/rdo rje'i chang bzung (5) dril bu'i lce (6)/, see Sangs rgyas rgya mtsho 1997, smad cha, p. 268.19-21. For the German translation, see Maurer 2009, pp. 139, 243.

99. stag gi 'dzum par mi thub ste/ ya rabs 'dod na de la gdab/, see Maurer 2009, pp. 140, 245.

100. rgyan drug dar klubs rlung bskyod 'dra / stag glang mi yi rgyal mtshan dang / khrag thig zhag zo thal chen tshom/, see Sangs rgyas rgya mtsho 1997, smad cha, p. 274.4-5. For the German translation, see Maurer 2009, p. 261. According to L. S. Dagyab (personal communication) the terms zhag zo, zhag gi zo ris or zhag sor ris denote the three lines on the forehead like those for example of the followers of Śiva. Boord 1993, p. 80, translates zhag gi zo ris as "a smear of fat".

101. See the depiction in Feuchtwang 1974, p. 158.

102. khang pa'i tho phyir sa pha bong / kha phyir gdangs pa rnams kyang bzang / pha bong phyed nyal sgo gtan yin /'og na pha bong stag gzugs yod / sgo rtsar shug pa yod pa dang / shar dang shar lhor mtsho yod bzang //, see Sangs rgyas rgya mtsho 1997, smad cha, p. 262.6-7. For the German translation, see Maurer 2009, p. 222.

103. The diviner bSod nam rdo rje, Medical-Astrological-Institute in Dharmasala, explained it as the bottom edge of a blossom.

104. dpa' bor 'gro ba'i sa drug ni / seng ge'i mthong ga (1) stag lba ba (2) / glang chen mkhal khung (3) khra sngon gshog (4) / rgod po'i ham tshugs (5) skye bo'i brang (6) / dbul po phyug por 'gro sa drug / 'khor ba (1) rgya mtsho'i mdud pa dang / brum rtser (2) mar khu (3) u skyu (4) dang / stag gi lto tshil (5) ba glang mkhal (6)/, see Sangs rgyas rgya mtsho 1997, smad cha, p.268.7-10. For the German translation, see Maurer 2009, p. 242.

105. Maurer 2009, pp. 239-240. The quality of the places is gendered: the queen trails the king in the order, followed by the minister. A building erected at a place resembling the queen, however, lasts only for seven generations, whereas a building at the minister's place lasts for nine generations.

106. nang gi rten 'brel bcu gsum ni / khyung dang thang dkar la sogs bya / gangs brag nags la gnas dang gcig / seng stag gcan gzan gnas dang gnyis / sha rkyang ri dvags 'phyo dang gsum/gnag lug spang la skyong dang bzhi / dung dang chu srin la sogs pa / chur gnas sna tshogs chur yod lnga / rta glang la sogs dkor nor tshogs/, see Sangs rgyas rgya mtsho 1997, smad cha, p. 272.7-10. For the German translation, see Maurer 2009, p. 257.

107. See Maurer 2009, pp. 206, 212. 
108. The term sgron seems to be related to some kind of of visual contact. The astrologer Tshe rnam understood it as some kind of dazzlement. Thus, chu sgron for example is caused by the reflection of the sun in the water. As there are terms like yak sgron, zur sgron etc. a connection with the elements is not very likely. Jackson, see Thubten Legshay Gyatsho 1979, p 29, translates it as "defect"; in his text five types, namely gnam sgron, brag sgron, sa sgron, chu sgron and shing sgron, are distinguished. The description there is, however, completely different from that in the Vaidūrya dkar po. Meyer \& Jest 1987, pp. 152 and 166, note for sgron "une lumière néfaste sur des éléments du paysage".

109. khang dur zhing sa thams cad la/gdams pa 'di ltar gces pa yin/rdza la shar du stag skya'i gzugs / lho ru 'brug sngon nub bya dmar / byang du rus sbal nag po'i gzugs / khog stod nang du shog bu la / bde legs yon tan thams cad kun/'dir 'dus bkra shis 'phel ba dang/sa grags mgyogs pa 'dir 'dus shig / sa shing chu brag sgron la sogs / sa dgra ngan pa thams cad kun/shar gyi phyogs nas stag skyas zlog/ces sogs bsgyur la so sor bcug/ sman 'bru rin chen dar sna dang/gla rtsi la sogs dri bzang tshogs / dkar mngar rnam gsum bcas pa bcug //, see Sangs rgyas rgya mtsho 1997, smad cha, p. 277.4-9. For the German translation, see Maurer 2009, pp. 268-269.

110. The term klung could refer to a river.

111. Lin 2005, pp. 304-305.

112. dur la phyi bsrung lha bzhi dgos / bar bsrung gad rnying shar phyogs su / bye'u stag la zhon zhes dang / lho ru zangs sprel 'brug zhon zhes / nub tu lcags sprel bya zhon zhes / byang du gser sprel sbal zhon zhes/, see Sangs rgyas rgya mtsho 1997, smad cha, p. 276.21-23. For the German translation, see Maurer 2009, p. 268.

113. Blo bzang chos 'phel describes this item as a wooden square or a kind of ladder with coloured threads in its middle, similar to a nam mkha'. It is used to repel demons. NebeskyWojkowitz [1956] 1993, pp. 17, 270, 358f., mentions a khram shing as a magical weapon against demons.

114. yang na de steng mchod rten bya / nub byang stag skya rgyu srang bcad / yang na shing gi khrom gnyer bstan / lho byang 'brug sngon zam pa bya / lho yi rus sbal khyung ngam sgrib / byang gi bya dmar brag gis mnan / shing skam gang na 'dug kyang bcad / khyung glang 'dra la seng ge bstan / seng ge 'dra la mchod rten bstan / chu rgyun sa yi srubs sa dbye //, see Sangs rgyas rgya mtsho 1997, smad cha, p. 254.25-28. For the German translation, see Maurer 2009, p. 204.

115. shar phyogs rgyal po yul 'khor srung / dri za'i tshogs dang bcas rnams la / mchod sbyin gtor ma 'di 'bul lo / sa 'di bslang bar mdzad du gsol / dri za'i rgyal po yul 'khor srung/ston pa'i bstan pa bsrung mdzad cing / rdo rje rigs kyi 'phrin las sgrubs / shar phyogs dri za'i gdon bcas kun / bsrung dang mtshams kyi las mdzod cig / ces brjod shar nas rdo dkar po / phyag gang ba blangs shar du bzhag / shar nas stag skya spyan 'dren no/sa 'di bslangs la yon bdag gi / kha 'dzin mdzod cig bu tsha bo/phan mdzangs rta gnag rkang bran sogs/'phel bar byed pa'i lha yin te/khyed kyang thang bzhugs mkhar grogs mdzod / mtshams bzhi'i sa dgra thub par gyis / zhes dang/, see Sangs rgyas rgya mtsho 1997, smad cha, p. 283.20-26. For the German translation, see Maurer 2009, pp. 288-290.

116. Maurer 2009, p. 305.

117. I would like to thank Zhao Lu, IKGF Erlangen-Nuremberg for the reference. The depiction is from the manuscript Pelliot Tibétain Chinois2964, Biliothèque Nationale de France; see https:// gallica.bnf.fr/ark:/12148/btv1b8302295m/f3.image.r=pelliot\%20chinois\%202964 (accessed 8 February 2018)

118. Tseng 2005, p. 59. 


\section{ABSTRACTS}

This article focuses on the tiger as one of the most significant animals in Tibetan geomancy ( $s a$ dpyad). Many of the Tibetan concepts that the tiger represents in geomancy originate in Chinese fengshui 風水 where the animal functions among others as a cosmic force. The animal is used as a pattern to describe and interpret the shape of a space in order to predict the life of the future inhabitants. The idea behind this method is that a space's outward appearance affects the lives of its inhabitants, either by independently or together with the zodiac signs, the agents and other dimensions calculated in Sino-Tibetan or Chinese prognostication (nag rtsis). The article introduces the various roles of the tiger in sa dpyad and fengshui. It also details the animal's role in other Tibetan traditions such as Bon, and its adaptation in geomantic ritual.

Cet article met l'accent sur le tigre comme l'un des animaux les plus importants de la géomancie tibétaine ( $s$ dpyad). La plupart des concepts tibétains que le tigre représente en géomancie trouvent leur origine dans le fengshui chinois, dans lequel l'animal fonctionne entre autres comme une force cosmique. Il est utilisé comme un modèle pour décrire et interpréter la forme d'un espace afin de prédire la vie des futurs habitants. L'idée sous-jacente à cette méthode est que l'aspect extérieur d'un espace affecte la vie de ses habitants, soit indépendamment, soit conjointement avec les signes du zodiaque, les agents et autres dimensions calculées dans l'astrologie sino-tibétaine ou chinoise (nag rtsis). L'article présente les différents rôles du tigre dans le sa dpyad et le fengshui. Il décrit également le rôle de l'animal dans d'autres traditions tibétaines, telles que le Bon, et son adaptation au rituel géomantique et à l'art tibétain.

\section{INDEX}

Keywords: Tibet, divination, geomancy, fengshui, symbolism, ritual, art

Mots-clés: Tibet, divination, géomancie, symbolisme, rituel, art

\section{AUTHOR}

\section{PETRA MAURER}

Prof. Dr. Petra Maurer received her doctoral degree in Tibetan Studies at the RheinischeFriedrich-Wilhelms-University in Bonn; she habilitated at the Ludwig-Maximilians-University (LMU) in Munich. Presently, she works at the "Wörterbuch der tibetischen Schriftsprache" in the Bavarian Academy of Sciences and Humanities. She teaches Tibetan language, culture and religion at the LMU. Before joining the LMU she lectured at Bonn University and worked in research projects sponsored by the German Research Foundation. Her scholarly interests range from Tibetan Buddhism and traditional sciences, such as divination and medicine to the cultural history of Tibet, including modern history and language.

phmaurer@zos.badw.de 